\title{
Molecular and Functional Heterogeneity of Hyperpolarization- Activated Pacemaker Channels in the Mouse CNS
}

\author{
Bina Santoro, ${ }^{1}$ Shan Chen, ${ }^{2}$ Anita Lüthi, ${ }^{5}$ Paul Pavlidis,, ${ }^{1}$ Gleb P. Shumyatsky, ${ }^{1}$ Gareth R. Tibbs, ${ }^{2,3}$ and \\ Steven A. Siegelbaum ${ }^{1,2,4}$ \\ ${ }^{1}$ Center for Neurobiology and Behavior, Departments of 2 Pharmacology and ${ }^{3}$ Anesthesiology, and ${ }^{4}$ Howard Hughes \\ Medical Institute, Columbia University, New York, New York 10032, and 5Section of Neurobiology, Yale University, New \\ Haven, Connecticut 06510
}

The hyperpolarization-activated cation current (termed $I_{\mathrm{h}}, I_{\mathrm{q}}$, or $I_{f}$ ) was recently shown to be encoded by a new family of genes, named HCN for hyperpolarization-activated cyclic nucleotidesensitive cation nonselective. When expressed in heterologous cells, each HCN isoform generates channels with distinct activation kinetics, mirroring the range of biophysical properties of native $I_{\mathrm{h}}$ currents recorded in different classes of neurons. To determine whether the functional diversity of $I_{\mathrm{h}}$ currents is attributable to different patterns of HCN gene expression, we determined the mRNA distribution across different regions of the mouse CNS of the three mouse $\mathrm{HCN}$ genes that are prominently expressed there (mHCN1, 2 and 4). We observe distinct patterns of distribution for each of the three genes. Whereas $\mathrm{mHCN} 2$ shows a widespread expression throughout the CNS, the expression of $\mathrm{mHCN} 1$ and $\mathrm{mHCN} 4$ is more limited, and generally complementary. $\mathrm{mHCN} 1$ is primarily expressed within neurons of the neocortex, hippocampus, and cerebellar cortex, but also in selected nuclei of the brainstem. mHCN4 is most highly expressed within neurons of the medial habenula, thalamus, and olfactory bulb, but also in distinct neuronal populations of the basal ganglia. Based on a comparison of mRNA expression with an electrophysiological characterization of native $I_{\mathrm{h}}$ currents in hippocampal and thalamic neurons, our data support the idea that the functional heterogeneity of $I_{\mathrm{h}}$ channels is attributable, in part, to differential isoform expression. Moreover, in some neurons, specific functional roles can be proposed for $I_{\mathrm{h}}$ channels with defined subunit composition.

Key words: Ih; pacemaker channel; hippocampus; thalamus; in situ hybridization; HCN
Hyperpolarization-activated cation channels, first identified in cardiac sinoatrial node cells, are found in a variety of peripheral and central neurons (for review, see DiFrancesco, 1993; Pape, 1996). These channels slowly activate in response to hyperpolarization to generate inward currents, termed $I_{f}$ in cardiac cells and $I_{\mathrm{h}}$ in neurons. In spontaneously firing nerve and muscle cells, $I_{\mathrm{h}}$ contributes to the pacemaker depolarization that generates rhythmic activity (McCormick and Bal, 1997). In nonpacing cells, $I_{\mathrm{h}}$ helps determine resting membrane properties and limits the extent of hyperpolarizing or depolarizing responses (Pape, 1996). $I_{\mathrm{h}}$ channels are also present in dendrites (Magee, 1998, 1999) and presynaptic terminals (Fletcher and Chiappinelli, 1992; Beaumont and Zucker, 2000), where they regulate synaptic transmission. The rate of $I_{\mathrm{h}}$ activation is enhanced by the direct binding of cAMP to the channel, providing a powerful means to regulate excitability (DiFrancesco and Tortora, 1991; Ingram and Williams, 1996).

The diverse roles of $I_{\mathrm{h}}$ are mirrored in the heterogeneous biophysical properties observed in the various cells in which this current is expressed (Santoro and Tibbs, 1999). Thus, two important questions arise: What is the molecular basis for this diversity? And how are the dynamic and modulatory properties of $I_{\mathrm{h}}$ tuned to specific neuronal functions? The recent cloning of four mammalian $I_{\mathrm{h}}$ genes, termed HCN1-4 for hyperpolarization-activated cyclic nucleotide-sensitive cation nonselective channels (Santoro et al., 1997, 1998; Ludwig et al., 1998, 1999; Ishii et al., 1999; Seifert et al., 1999; Vaccari et al., 1999; Moroni et al., 2000) (for review, see

Received March 13, 2000; revised April 28, 2000; accepted May 3, 2000.

This work was partially supported by a grant from the Whitehall Foundation (G.R.T.) and National Institutes of Health Grant NS-36658 (S.A.S.).We thank Huan Yao, John Riley, Matthew DeGennaro, and Eric Odell for technical assistance and Cliff Kentros, Eric Kandel, and David McCormick for helpful comments on this manuscript.

Correspondence should be addressed to Bina Santoro, Center for Neurobiology and Behavior, 722 West 168th Street, New York, NY 10032. E-mail: bs73@columbia.edu. Copyright (C) 2000 Society for Neuroscience $0270-6474 / 00 / 205264-12 \$ 15.00 / 0$
Clapham, 1998; Santoro and Tibbs, 1999), now allows such questions to be studied.

Three of the four HCN genes have been heterologously expressed, where they generate hyperpolarization-activated currents with distinct biophysical characteristics. HCN1 channels activate relatively rapidly on hyperpolarization (in tens of milliseconds) and show a minimal response to cAMP (Santoro et al., 1998). HCN2 channels activate more slowly (hundreds of milliseconds) and are modulated strongly by cAMP (Ludwig et al., 1998, 1999; Santoro and Tibbs, 1999). Finally HCN4 channels activate very slowly (seconds) and respond strongly to cAMP (Ishii et al., 1999; Ludwig et al., 1999; Seifert et al., 1999). This functional diversity of recombinant $\mathrm{HCN}$ channels suggests that differential $\mathrm{HCN}$ gene expression may generate the heterogeneity in native $I_{\mathrm{h}}$ currents.

Initial studies of mRNA distribution showed that all four mouse $\mathrm{HCN}$ isoforms are expressed in the brain, although with different regional distributions and at different levels (Santoro et al., 1997, 1998; Ludwig et al., 1998; Moosmang et al., 1999). mHCN1 is strongly expressed in cortical areas; $\mathrm{mHCN} 2$ is widely expressed at a high level throughout the brain; $\mathrm{mHCN} 3$ is also widely expressed, but at very low levels; and mHCN4 shows strong subcortical expression. $\mathrm{mHCN} 2$ and $\mathrm{mHCN} 4$ are also strongly expressed in the heart. However, many of the details of the cellular distribution of $\mathrm{mHCN}$ in regions that exhibit prominent $I_{\mathrm{h}}$ are lacking. In this study we present a detailed mapping of $\mathrm{HCN}$ isoform expression in the brain and spinal cord for the three mouse $\mathrm{HCN}$ genes that are strongly expressed in the CNS (mHCN1, mHCN2, and mHCN4). By comparing recombinant HCN channel properties with native $I_{\mathrm{h}}$ from thalamic and hippocampal neurons, we suggest specific functional roles for the different $\mathrm{mHCN}$ isoforms.

\section{MATERIALS AND METHODS}

\section{In situ hybridization}

In situ hybridization was performed essentially as described (SchaerenWiemers and Gerfin-Moser, 1993). Adult male C57Bl/6 mice were killed by cervical dislocation, and the brains removed and quickly frozen in OCT 
(Tissue-Tek) compound. Coronal cryostat sections $(20 \mu \mathrm{m})$ were prepared on Superfrost Plus (VWR Scientific) slides, fixed in $4 \%$ paraformaldehyde-PBS, and acetylated (triethanolamine-acetic anhydride). Coordinates for coronal sections shown in Figures 1-7 are according to Franklin and Paxinos (1997).

Prehybridization was performed for $1 \mathrm{hr}$ at room temperature (RT) in $50 \%$ formamide, $5 \times \mathrm{SSC}, 5 \times$ Denhardt's solution, $0.25 \mathrm{mg} / \mathrm{ml} \mathrm{tRNA}$, and $0.5 \mathrm{mg} / \mathrm{ml}$ salmon sperm DNA, followed by hybridization overnight at $68^{\circ} \mathrm{C}$ in the same buffer including $200-400 \mathrm{ng} / \mathrm{ml}$ riboprobe (see below) Slices were washed at $68^{\circ} \mathrm{C}$ in $0.2 \times \mathrm{SSC}$, blocked for $1 \mathrm{hr}$ at RT in $0.1 \mathrm{M}$ Tris, $\mathrm{pH} 7.5,0.15 \mathrm{M} \mathrm{NaCl}+10 \%$ inactivated goat serum (Sigma, St. Louis, $\mathrm{MO}$ ), and incubated overnight at $4{ }^{\circ} \mathrm{C}$ in the same buffer $+1 \%$ goat serum and 1:5000 dilution of anti-DIG antibody coupled to alkaline phosphatase (Boehringer Mannheim, Mannheim, Germany). The staining reaction was performed for 24-48 $\mathrm{hr}$ at RT in $0.1 \mathrm{M}$ Tris, $\mathrm{pH} 9.5,0.1 \mathrm{M} \mathrm{NaCl}, 50 \mathrm{~mm}$ $\mathrm{MgCl}_{2}, 0.24 \mathrm{mg} / \mathrm{ml}$ levamisole, $0.225 \mathrm{mg} / \mathrm{ml}$ nitroblue tetrazolium, and $0.175 \mathrm{mg} / \mathrm{ml}$ 5-bromo-4-chloro-3-indolyl-phosphate (Promega, Madison, WI). Slides were washed in $10 \mathrm{~mm}$ Tris, pH 7.5, $1 \mathrm{~mm}$ EDTA and mounted in Fluoromount-G (Southern Biotechnology Associates, Birmingham, AL).

Antisense and sense riboprobes corresponding to amino acids 777-910 of $\mathrm{mHCN} 1,322-612$ of $\mathrm{mHCN} 2$, and $400-690$ of $\mathrm{mHCN} 4$ were in vitro transcribed in the presence of 3.5:6.5 digoxigenin-UTP:UTP (Boehringer Mannheim) according to the manufacturer's instructions. Control hybridizations performed in the presence of sense RNA probes did not yield any detectable signals with staining reactions of up to $72 \mathrm{hr}$ (data not shown).

\section{Electrophysiology}

Native currents. Hippocampal or thalamic slices $(400 \mu \mathrm{m})$ were prepared from 2.5- to 4-week-old $\mathrm{C} 57 \mathrm{Bl} / 6$ mice using a gravity-driven chopper (hippocampal slices) or a Vibratome (thalamic slices). After at least $1 \mathrm{hr}$ of recovery, slices were transferred to a submerged recording chamber perfused $(1-2 \mathrm{ml} / \mathrm{min}$ ) with artificial CSF (ACSF) containing (mM): $\mathrm{NaCl}$ 119; $\mathrm{KCl} 5 ; \mathrm{MgSO}_{4} 1 ; \mathrm{CaCl}_{2} 2 ; \mathrm{NaHCO}_{3} 26.2 ; \mathrm{NaH}_{2} \mathrm{PO}_{4} 1$; and dextrose 11; bubbled with $95 \% \mathrm{O}_{2}$ and $5 \% \mathrm{CO}_{2}$. The temperature of the chamber was maintained at $32-34^{\circ} \mathrm{C}$.

Whole-cell recordings were obtained from visually identified pyramidal cells, interneurons, thalamocortical cells, and reticular cells using infrareddifferential interference contrast microscopy (Dodt and Zieglgansberger, 1990). For hippocampal recordings, electrodes were pulled from borosilicate glass to a resistance of 3-5 M $\Omega$ and filled with (in mM): $120 \mathrm{KMeSO}_{4}$, $20 \mathrm{KCl}, 10 \mathrm{HEPES}, 4.0 \mathrm{Mg}_{2}$-ATP, $0.3 \mathrm{Na}_{2}$-GTP, 14 phosphocreatine, 4 $\mathrm{NaCl}$, and $0.5 \mathrm{~mm}$ EGTA, pH 7.25 with $\mathrm{KOH}$. All current records were made within $10 \mathrm{~min}$ of attaining whole-cell access. Interneurons were identified by the position and morphology of the cell body as well as by electrophysiological characteristics, including a relative lack of action potential accommodation and short, brief action potentials as compared to pyramidal cells. Thalamic recordings were done with pipettes filled with (in mM): $110 \mathrm{~K}$ gluconate, $10 \mathrm{KCl}, 10 \mathrm{HEPES}, 2 \mathrm{MgCl}_{2}, 2 \mathrm{Na}_{2} \mathrm{ATP}, 0.2$ NaGTP, 0.02 calmodulin, and 290 mOsm, pH 7.25, as previously described (Lüthi and McCormick, 1999). Series resistance of 5-12 M $\Omega$ was electronically compensated $32-80 \%$. A liquid junction potential of 7-8 $\mathrm{mV}$ measured as described (Neher, 1992) was taken into account for all the data. Thalamocortical cells were identified electrophysiologically by their robust rebound burst firing after transient membrane hyperpolarization, whereas nRT neurons displayed a burst-tonic action potential discharge.

Oocyte recordings. mHCN1 and mHCN2 (Ludwig et al., 1998; Santoro et al., 1998) were subcloned into the pGHE expression vector. RNA was transcribed from NheI-linearized DNA (mHCN1) or SphI-linearized DNA (mHCN2) using T7 RNA polymerase (Message Machine; Ambion, Houston, TX) and injected into Xenopus oocytes prepared as previously described (Santoro et al., 1998). Two microelectrode voltage-clamp recordings were obtained 1-2 d after cRNA injection using a Warner Instruments (Hamden, CT) OC-725B amplifier. Data were digitized and acquired using an ITC-18 interface (Instrutech) and acquired and analyzed with Pulse and PulseFit software (Heka Electronics). Data were filtered at 250 $\mathrm{Hz}$ and sampled at $500 \mathrm{~Hz}$ for most experiments. For some mHCN1 data, currents were filtered at $1 \mathrm{kHz}$ and sampled at $2 \mathrm{kHz}$. Custom analysis routines were written with IgorPro. We used a high- $\mathrm{KCl}$ extracellular solution to maximize the amplitude of the $I_{\mathrm{b}}$ currents. The solution contained (in mM): $96 \mathrm{KCl}, 2 \mathrm{NaCl}, 10 \mathrm{HEPES}$, and $2 \mathrm{MgCl}_{2}$, pH 7.5, with $\mathrm{KOH}$. The microelectrodes were filled with $3 \mathrm{M} \mathrm{KCl}$ and had resistances of $0.5-1.5 \mathrm{M} \Omega$. All recordings were obtained at room temperature $\left(23-25^{\circ} \mathrm{C}\right)$.

\section{Analysis}

"Steady-state" activation curves were determined from the amplitude of tail currents observed after hyperpolarizing voltage steps on return to -40 $\mathrm{mV}$ for recombinant currents and the given holding potential for native currents. Tail current amplitudes were measured after the decay of the capacitive transient by averaging the current during the plateau of the tail (between 35 and $50 \mathrm{msec}$ after the return to $-40 \mathrm{mV}$ for $\mathrm{mHCN} 1$ and between 80 and $100 \mathrm{msec}$ for $\mathrm{mHCN} 2$ ). Changing the time window had no effect on activation curves. Current values were plotted versus the hyperpolarization step voltage and fitted with the Boltzmann equation:

$$
I(V)=A_{1}+A_{2} /\left\{1+\exp \left[\left(\mathrm{V}-\mathrm{V}_{1 / 2}\right) / \mathrm{s}\right]\right\}
$$

where $A_{1}$ is an offset caused by a nonzero holding current, $A_{2}$ is the maximal tail current amplitude, $V$ is voltage during the hyperpolarizing test pulse in millivolts, and $V_{1,2}$ is the activation midpoint voltage. For each experiment, the tail current data were fitted with the above equation. To average the activation data from different experiments, the tail current amplitudes, $I(V)$, from each individual experiment were normalized by first subtracting the derived $A_{1}$ parameter and then dividing by $A_{2}$. The normalized data at each voltage were then averaged, and the averaged data were fitted by the Boltzmann equation (with $A 1$ set at 0 and $A 2$ set at 1). These normalized curves have been plotted in the indicated figures.

The rate of channel activation of $I_{\mathrm{h}}$ in the various cell types was determined by fitting the current evoked during hyperpolarizing voltage steps to single or double exponential functions in IgorPro. For all cell types where there was measurable $I_{\mathrm{h}}$, simultaneous fitting with two exponential components yielded fits that were significantly better than single exponential terms for all currents activated in response to steps to potentials that were negative to the steady-state midpoint voltage of activation $\left(V_{1 / 2}\right)$; the fit was not improved after addition of a third component. $I_{\mathrm{h}}$ currents in certain types of native neurons and for certain isoforms exhibit a distinct lag in their activation time course that is not described by the one or two exponential function fits. We have therefore excluded the initial lag from the fitting procedure. The purpose of these fits was solely to provide an empirical description of current kinetics that allows us to compare directly our results with previous studies on native and recombinant channels and do not imply a particular model for current activation (Moroni et al., 2000).

To exclude the uncompensated capacitive transients and activation delay of $I_{\mathrm{h}}$ currents in different cell types, it was necessary to use slightly different windows for the fits. For the rapidly activating HCN1 currents, we excluded the first $10-20 \mathrm{msec}$ of the current traces. For the slowly activating HCN2 currents, we excluded the first $180-250 \mathrm{msec}$ of the current traces. For native $I_{\mathrm{h}}$ currents, we excluded the first $20 \mathrm{msec}$ of the current trace for CA1 pyramidal and stratum oriens neurons; the first $40-100 \mathrm{msec}$ of the records were excluded for stratum radiatum neurons, and the first $44 \mathrm{msec}$ were excluded for thalamic neurons. All traces were then fit in a window extending from this initial point to within a few percent of the end of the current record. For CA3 pyramidal neurons, the $I_{\mathrm{h}}$ currents were generally too small to fit. Data are presented as mean $\pm \mathrm{SE}$

\section{RESULTS}

\section{Three members of the $\mathrm{mHCN}$ gene family show a differential and complementary pattern of expression in neurons across the mouse CNS}

Digoxigenin-labeled riboprobes were generated for each of the mouse $\mathrm{mHCN} 1, \mathrm{mHCN} 2$, and $\mathrm{mHCN} 4 \mathrm{cDNAs}$, and in situ hybridization was performed on coronal sections taken from mouse brain and spinal cord. As previously reported, all three isoforms are expressed throughout the CNS, but each one exhibits a distinct and often complementary pattern of distribution (Santoro et al., 1997; Ludwig et al., 1998; Moosmang et al., 1999). Below we present detailed localization of $\mathrm{mHCN}$ transcripts in cell types within regions of the brain that show distinctive patterns of HCN mRNA expression and/or in which prominent $I_{\mathrm{h}}$ currents have been reported (see Figs. 1-7). In general, considerable overlap in expression is found between $\mathrm{mHCN} 1$ and $\mathrm{mHCN} 2$, as well as between mHCN2 and mHCN4; however, very little overlap exists between mHCN1 and mHCN4 (Table 1).

\section{Olfactory bulb}

Prominent labeling was found in this region for the mHCN2 and mHCN4 transcripts (Fig. 1). Both isoforms are highly expressed in type I and type II (displaced) mitral cells, and labeling is also found in tufted cells. However, mHCN4 probes appear to label a larger number of externally placed tufted cells (Fig. $1 B$ ) compared to mHCN2 transcripts (Fig. $1 A$ ). Finally, mHCN2 probes also distinctively label a scattered population of small cells present throughout the granule, internal and external plexiform, and glomerulal layers, which are likely to correspond to the short-axon cells, a type of inhibitory intrinsic neuron (Fig. 1A).

\section{Basal forebrain}

We were particularly interested in examining the patterns of expression of $\mathrm{mHCN}$ isoforms in regions of the brain that control oscillatory electrical activity. It is thus intriguing that high levels of mHCN2 expression are present in the medial septum, as well as in the vertical and horizontal limb of the diagonal band (Fig. 2A). These structures are important for generating the theta rhythm in 
Table 1. HCN mRNA expression in mouse CNS

\begin{tabular}{|c|c|c|c|}
\hline Brain region & mHCN1 & $\mathrm{mHCN} 2$ & $\mathrm{mHCN} 4$ \\
\hline \multicolumn{4}{|l|}{ Olfactory bulb } \\
\hline Glomerular layer/EPL & $+1-$ & ++ & ++ \\
\hline Mitral cell layer & $+/-$ & ++++ & ++++ \\
\hline Granule cell layer/IPL & $+1-$ & ++ & $+1-$ \\
\hline \multicolumn{4}{|l|}{ Basal forebrain } \\
\hline Striatum & - & ++ & + \\
\hline Globus pallidus & - & ++ & + \\
\hline Septum/diagonal band & + & +++ & + \\
\hline \multicolumn{4}{|l|}{ Amygdala } \\
\hline Basomedial ant. nucl. & - & $+1-$ & ++ \\
\hline Basolateral nucleus & + & + & + \\
\hline Central nucleus & + & $+1-$ & $+1-$ \\
\hline Lateral nucleus & $+/-$ & $+1-$ & + \\
\hline \multicolumn{4}{|l|}{ Cerebral cortex } \\
\hline Neocortex & +++ & ++ & $+1-$ \\
\hline Piriform cortex & + & + & + \\
\hline \multicolumn{4}{|l|}{ Hippocampus } \\
\hline Pyramidal cells (CA1) & +++ & ++ & $+1-$ \\
\hline Pyramidal cells (CA3) & ++ & +++ & + \\
\hline Stratum oriens & ++ & ++ & $+1-$ \\
\hline Stratum radiatum/L-M & ++ & ++ & $+1-$ \\
\hline Granule cells (DG) & $+/-$ & + & - \\
\hline Hilus of dentate gyrus & ++ & ++ & - \\
\hline \multicolumn{4}{|l|}{ Thalamus } \\
\hline Anterodorsal nucleus & + & +++ & ++ \\
\hline Principal relay nuclei & - & ++++ & +++ \\
\hline Geniculate nuclei & - & ++++ & ++ \\
\hline Nucleus reticularis & - & +++ & $+1-$ \\
\hline Lateral habenula & - & ++ & ++ \\
\hline Medial habenula & - & $+1-$ & ++++ \\
\hline Subthalamic nucleus & $+1-$ & +++ & $+1-$ \\
\hline \multicolumn{4}{|l|}{ Hypothalamus } \\
\hline Preoptic nuclei & - & +++ & ++ \\
\hline Ventromedial nuclei & ++ & $+1-$ & $+1-$ \\
\hline Mammillary nuclei & + & + & + \\
\hline \multicolumn{4}{|l|}{ Midbrain } \\
\hline Superior colliculus & ++ & ++ & $+1-$ \\
\hline Inferior colliculus & ++ & ++ & $+1-$ \\
\hline Substantia nigra & $+1-$ & ++ & + \\
\hline \multicolumn{4}{|l|}{ Cerebellum } \\
\hline Molecular cell layer & ++ & - & - \\
\hline Purkinje cell layer & +++ & + & - \\
\hline Granule cell layer & - & ++ & - \\
\hline Deep cerebellar nuclei & $+1-$ & ++++ & ++ \\
\hline \multicolumn{4}{|l|}{ Brainstem } \\
\hline Vestibular nucleus & $+/-$ & +++ & + \\
\hline Cochlear nucleus & ++ & +++ & + \\
\hline Spinal trigem. nucl. & ++ & +++ & + \\
\hline Facial nucleus & +++ & +++ & + \\
\hline Hypoglossal nucleus & +++ & +++ & + \\
\hline Reticular fields & + & +++ & + \\
\hline Inferior olive & + & + & - \\
\hline \multicolumn{4}{|l|}{ Spinal cord } \\
\hline Dorsal horn & + & ++ & $+1-$ \\
\hline Ventral horn & +++ & ++ & $+1-$ \\
\hline
\end{tabular}

++++ , Very high expression.

+++ , High expression.

++ , Moderate expression.

+ , Low expression.

$+/-$, Barely above background/background.

- , No detectable signal. the hippocampus, a prominent $5-10 \mathrm{~Hz}$ synchronous electrical oscillation associated with exploratory activity (for review, see Bland and Oddie, 1998; Vinogradova et al., 1998).

Notable $I_{\mathrm{h}}$ currents have been described in the giant cholinergic interneurons of the striatum. These cells exhibit pacemaker properties in vitro and are tonically active in vivo (Jiang and North, 1991; Kawaguchi, 1992, 1993). mHCN2 and mHCN4 transcripts are, in fact, found throughout the striatum, although in a relatively small number of cells (Fig. 2B,C). This sparse pattern of labeling is consistent with expression of $\mathrm{mHCN}$ transcripts within striatal interneurons, which represent $\sim 3-4 \%$ of the total cell population. In particular, mHCN4 appears to label only a restricted number of very large neurons, suggesting its presence in the giant cholinergic pacemaking interneurons (Fig. $2 C$ ).

Staining for mHCN2 and mHCN4 transcripts was found in the globus pallidus, in both the lateral (Fig. $2 B, C$ ) and medial (see Fig. $4 A, B)$ segment. Globus pallidus neurons comprise a class of neurons (type II) characterized by the presence of time- and voltagedependent inward rectification of the membrane potential evoked by hyperpolarizing current steps, and anodal break rebound depolarization, a hallmark of $I_{\mathrm{h}}$ currents (Stanford and Cooper, 1999). Labeling for mHCN2 and mHCN4 transcripts is also present in the other main nuclei of the basal ganglia system, namely the subthalamic nucleus (mHCN2; Table 1) and the substantia nigra (mHCN2 and mHCN4; see Fig. 5C,D).

Staining of the anterodorsal thalamic nucleus by both transcripts is also noticeable in Figure 2, $B$ and $C$. Furthermore, the reticular thalamic nucleus appears to be strongly labeled by $\mathrm{mHCN} 2$, but not by $\mathrm{mHCN} 4$ probes (see also below, Thalamus; see Fig. 4A,B).

\section{Cerebral cortex and hippocampus}

mHCN1 and mHCN2 transcripts are expressed at moderate to high levels in the neocortex, whereas mHCN4 appears to be essentially absent (Fig. 3A,C,E). The staining of mHCN1 shows a distinctively layered distribution, with most prominent labeling of the pyramidal cells in layer $\mathrm{V}$ (Fig. $3 A$; shown is sensorimotor cortex). This is consistent with the previous finding that the apical dendrites of layer $\mathrm{V}$ pyramidal neurons are strongly labeled by antimHCN1 antibodies (Santoro et al., 1997). In contrast, mHCN2 transcripts appear to have a more scattered distribution throughout the cerebral cortex, with a labeling of large and small neurons (Fig. 3C).

Similar to neocortex, both mHCN1 and mHCN2 transcripts are prominently expressed in the hippocampus, whereas mHCN4 is expressed at very low levels (Fig. $3 B, D, F$ ). Again, the staining patterns appear to be somewhat different for the two isoforms. Labeling for $\mathrm{mHCN} 1$ is strongest in the CA1 pyramidal cell layer, moderate in $\mathrm{CA} 3$, and almost absent in dentate granule cells (Fig. $3 B$ ). Labeling for $\mathrm{mHCN} 2$ is strongest in the CA3 pyramidal cell layer, moderate in CA1, and very low in dentate granule cells (Fig. $3 D)$. mHCN4 shows a very modest labeling, principally in area CA3 (Fig. $3 F$ ). These findings are in excellent agreement with the results reported by Moosmang et al. (1999), who used radioactive in situ labeling to characterize the expression of HCN mRNA isoforms in the hippocampus. Both $\mathrm{mHCN} 1$ and $\mathrm{mHCN} 2$ probes also label cells outside of the pyramidal cell layers, consistent with the reported presence of $I_{\mathrm{h}}$ in various types of hippocampal interneurons (see Fig. 10B; Williams et al., 1994; Maccaferri and McBain, 1996). mHCN1 shows a distinct labeling of a group of larger interneurons in the stratum oriens, which are most likely basket cells (Fig. 3B), consistent with the observed labeling of basket cell axon terminals by anti-mHCN1 antibodies (Santoro et al., 1997). Neurons at the stratum lacunosum-moleculare/radiatum border of area CA1 and larger cells in the hilus of the dentate gyrus also appear to be labeled by the mHCN1 probe (Fig. $3 B$ ). A scattered labeling of smaller interneurons located in stratum oriens, radiatum, lacunosum-moleculare (L-M), and the hilus of the dentate gyrus (DG) is observed for mHCN2 transcripts (Fig. 3D).

Strong labeling of the medial habenula is obtained with the mHCN4 probe (Fig. $3 F$ ), whereas $\mathrm{mHCN} 1$ and $\mathrm{mHCN} 2$ probes 

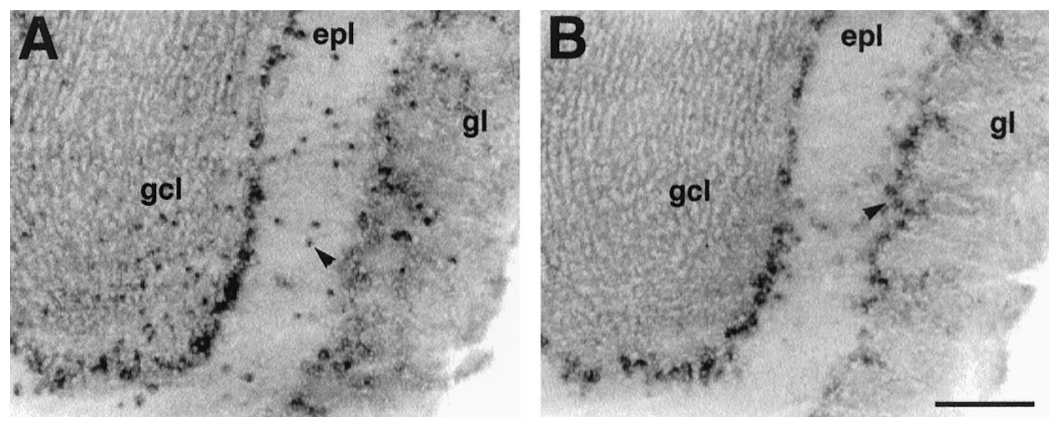

Figure 1. $\mathrm{mHCN} 2$ and $\mathrm{mHCN} 4$ are expressed in olfactory bulb. $A$, Coronal section (bregma, $+4.28 \mathrm{~mm}$ ) showing labeling by $\mathrm{mHCN} 2$ probe of mitral cells, tufted cells, and short-axon cells (arrowhead). B, mHCN4 transcripts are present in mitral cells and tufted cells (arrowhead shows externally placed tufted cells), but not in short-axon cells. gcl, Granule cell layer; epl, external plexiform layer; $g l$, glomerular layer. Scale bar, $200 \mu \mathrm{m}$.
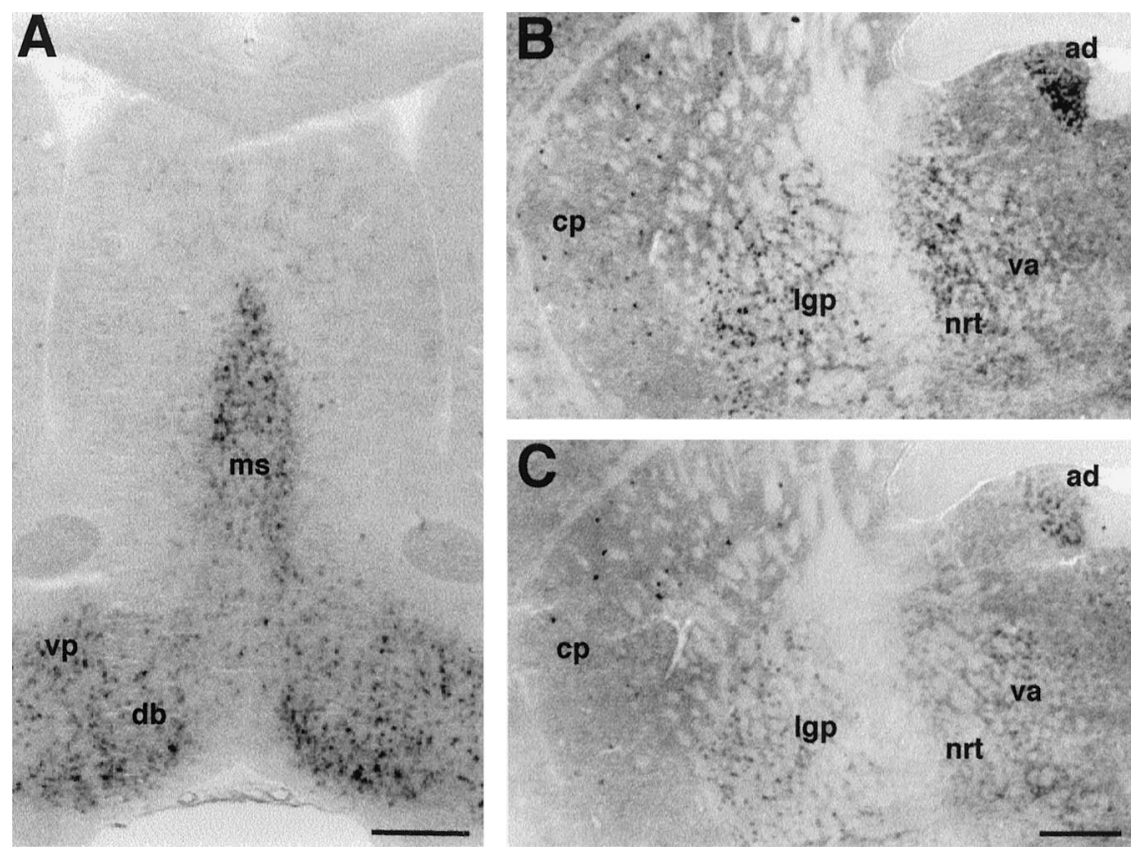

Figure 2. Expression of $\mathrm{mHCN} 2$ and $\mathrm{mHCN} 4 \mathrm{mRNA}$ in the mouse basal forebrain. $A$, Coronal section (breg$\mathrm{ma},+0.74)$ showing $\mathrm{mHCN} 2$ labeling in the medial septum $(m s)$, vertical and horizontal limb of the diagonal band $(d b)$, and ventral pallidum $(v p) . B$, Coronal section (bregma, -0.82) showing staining by the mHCN2 probe of cells in the caudate putamen $(c p)$, lateral globus pallidus $(\lg p)$, thalamus nucleus reticularis $(n r t)$, ventral anterior thalamic nucleus $(v a)$, and anterodorsal thalamic nucleus $(a d)$. $C$, Coronal section (bregma, -0.82 ) showing staining by the $\mathrm{mHCN} 4$ probe of cells in the caudate putamen, lateral globus pallidus, and anterodorsal thalamic nucleus. mHCN4 is not present in thalamus nucleus reticularis. Scale bars, 500 $\mu \mathrm{m}$.

show little staining in this region. This observation is particularly interesting in view of the fact that medial habenula neurons are spontaneously active, firing in a regular $2-6 \mathrm{~Hz}$ repetitive manner, while completely lacking the low-threshold $\mathrm{Ca}$ conductance that often interacts with $I_{\mathrm{h}}$ to generate spontaneous firing (McCormick and Prince, 1987). Both $\mathrm{mHCN} 2$ and $\mathrm{mHCN} 4$ are expressed in the lateral habenula (Fig. 3D,F).

\section{Thalamus}

A physiologically important role for $I_{\mathrm{h}}$ has been particularly well characterized in the thalamus. Thalamocortical relay neurons undergo transitions from burst firing modes to tonic firing modes during the sleep-wake cycle (for review, see McCormick and Bal, 1997; Lüthi and McCormick, 1998). This change in excitability results in part from a cAMP-dependent speeding of the kinetics of $I_{\mathrm{h}}$ activation. Consistent with the presence of high levels of $I_{\mathrm{h}}$ currents, a strong pattern of $\mathrm{mHCN} 2$ and mHCN4 staining was found in the principal relay nuclei of the thalamus, including the dorsal lateral geniculate nucleus (Figs. $3 D, F, 4 A, B$; Moosmang et al., 1999). In contrast, mHCN1 expression was not detected to any significant extent. In rodents, the ventral posterior nucleus of the thalamus does not contain local interneurons, thus, it is likely that the observed staining represents entirely thalamocortical relay neurons. As noted above (see Basal Forebrain; Fig. 2B,C), GABAergic neurons in the reticular nucleus thalami are positive for $\mathrm{mHCN} 2$ transcripts, whereas mHCN4 appears to be essentially absent from this region (Figs. $2 B, C, 4 A, B$ ).

Labeling for $\mathrm{mHCN}$ transcripts was also found in several nuclei of the hypothalamus (Table 1).

\section{Amygdala}

mHCN1, 2, and 4 are all expressed in the amygdala, but they show a very distinct distribution across different nuclei (Table 1). Thus, mHCN4 is present at a moderate level in the rostral portion of the basomedial nucleus and at a low to moderate level in the lateral and basolateral amygdaloid nuclei. A low level of expression of mHCN2 is found in the basolateral nucleus, whereas mHCN1 is expressed in both the basolateral and central nuclei (Table 1).

\section{Midbrain}

Labeling of the superior colliculus by the mHCN1 and mHCN2 probes is shown in Figure 5, $A$ and $B$, respectively. Whereas mHCN2 is expressed throughout this region, mHCN1 transcripts appear to be restricted to one layer in the superior colliculus, most likely the intermediate gray layer. Cells in the intermediate layer send descending motor commands to the brainstem and are involved in the control of saccadic eye movement. Electrophysiological data indicate the presence of a time-dependent inward rectifier current with properties consistent with $I_{\mathrm{h}}$ in a particular class of cells within this layer, namely the wide-field vertical cells (Saito and Isa, 1999). These cells exhibit extensive dendritic arborization into the superficial and optic nerve layer, where they receive the incoming visual information.

Labeling of the substantia nigra pars reticulata, a nucleus of the basal ganglia with a very similar cellular organization to the globus pallidus, was found for mHCN2 and at lower levels for mHCN4 transcripts (Fig. 5C,D). The mHCN4 probe also showed significant staining of the substantia nigra pars compacta (Fig. $5 D$ ). 

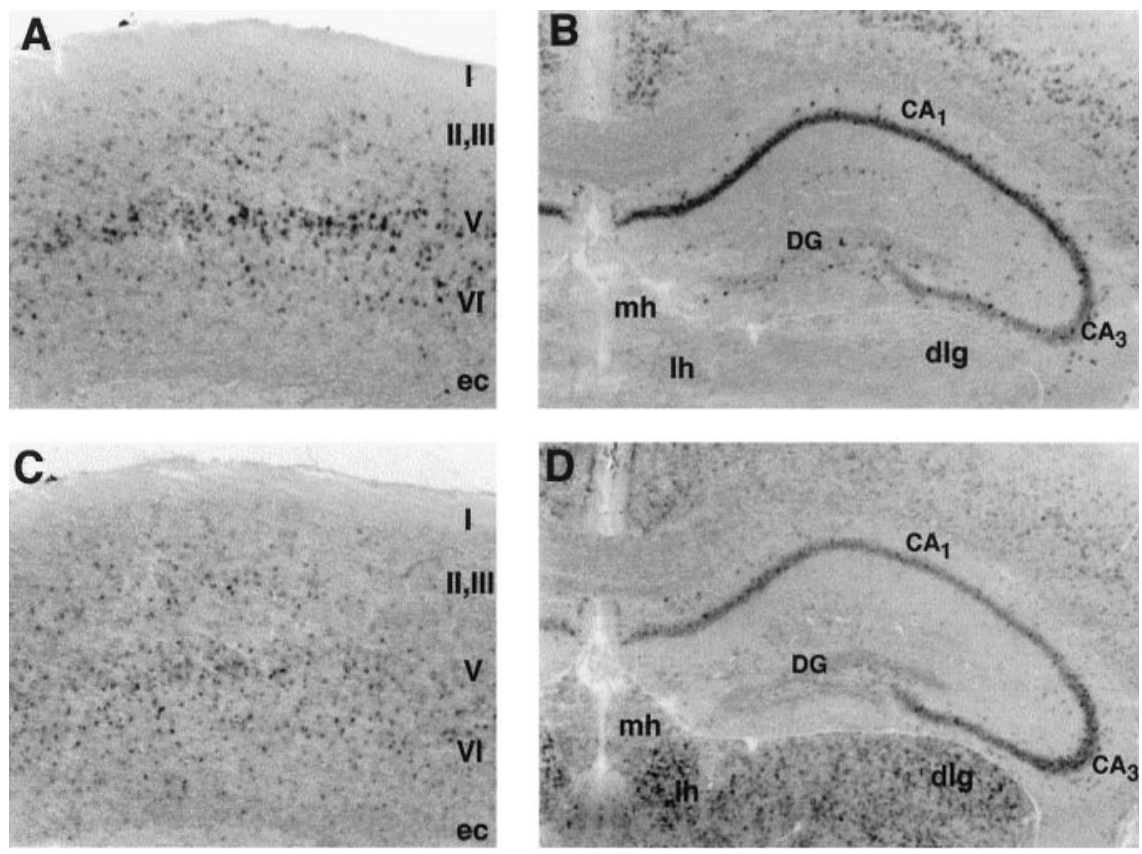

Figure 3. Differential distribution of mHCN1, mHCN2, and mHCN4 in the mouse cerebral and hippocampal cortex. $A$, Coronal section (bregma, +0.74 ) showing $\mathrm{mHCN} 1$ labeling in the motor cortex. $B$, Coronal section (bregma, -2.06) showing mHCN1 labeling in the hippocampus. $C$, mHCN2 labeling in the motor cortex. $D$, mHCN2 labeling in the hippocampus, lateral habenula, and dorsal lateral geniculate nucleus. $E$, mHCN4 labeling is absent in the motor cortex. $F$, mHCN4 labeling in the hippocampus, medial and lateral habenula, and dorsal lateral geniculate nucleus. $e c$, External capusle; $m h$, medial habenula; $l h$, lateral habenula; $d l g$, dorsal lateral geniculate nucleus; $D G$, dentate gyrus; $C A_{1} C A_{3}$ cornus ammonis fields $\mathrm{CA}_{1}$ and $\mathrm{CA}_{3}$. Scale bars, $500 \mu \mathrm{m}$.
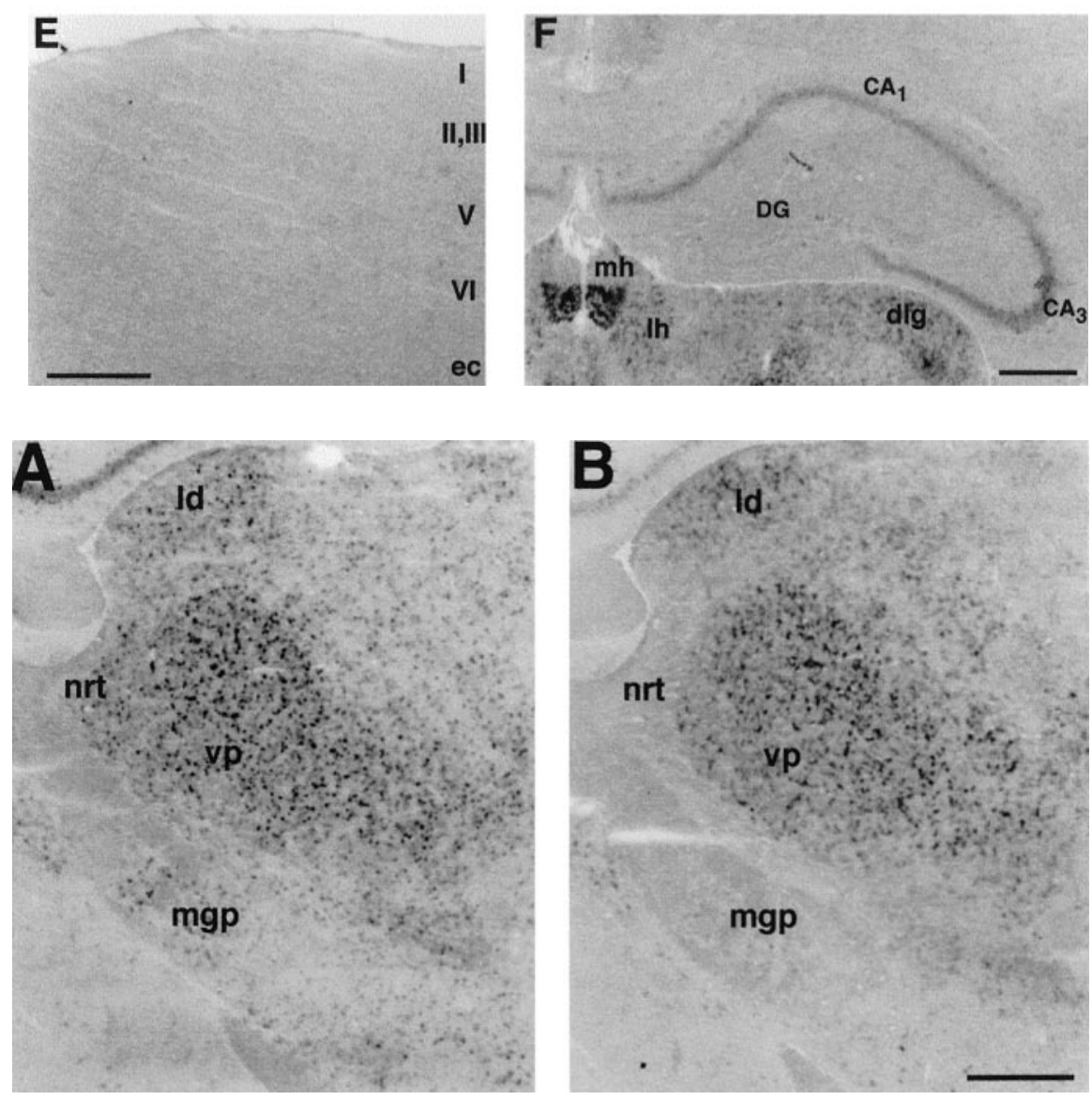

Figure 4. Expression of $\mathrm{mHCN} 2$ and $\mathrm{mHCN} 4$ in the showing labeling of laterodorsal $(l d)$, ventroposterior $(v p)$, and reticular $(n r t)$ thalamic nuclei by mHCN2 globus pallidus $(m g p)$. $B$, Labeling by $\mathrm{mHCN} 4$ probe of laterodorsal and ventroposterior thalamic nuclei. Weak labeling is also visible in the medial globus pallidus. Scale bar, $500 \mu \mathrm{m}$. mouse thalamus. $A$, Coronal section (bregma, -1.58) probe. Also visible is the labeling of cells in the medial

\section{Cerebellum}

In the cerebellar cortex, a strong labeling for $\mathrm{mHCN} 1$ was found in the Purkinje cell layer (Fig. 6A). Labeling for $\mathrm{mHCN} 1$ is also present in the molecular layer (weak labeling is visible in the experiment shown in Fig. 6A; Moosmang et al., 1999), most likely within the basket cells, whose axon terminals were previously found to be heavily stained by $\mathrm{mHCN} 1$ antibodies (Santoro et al., 1997). A low amount of mHCN2 is also present in Purkinje cells; the $\mathrm{mHCN} 2$ probe mainly labels a population of scattered cells within the granule cell layer. These cells may correspond to the Golgi cells (interneurons), but could also represent glial cells, because the labeling is also observed in the underlying white matter (Fig. 6B). The latter conclusion is supported by the presence of high levels of mHCN2 mRNA within the corpus callosum, as was previously determined by Northern blot analysis (Santoro et al., 1998). mHCN4 labeling is completely absent from the cerebellar cortex. In contrast, cells within the deep cerebellar nuclei exhibit strong labeling with both $\mathrm{mHCN} 2$ and $\mathrm{mHCN} 4$ probes (Fig. $6 B, C$ ). 

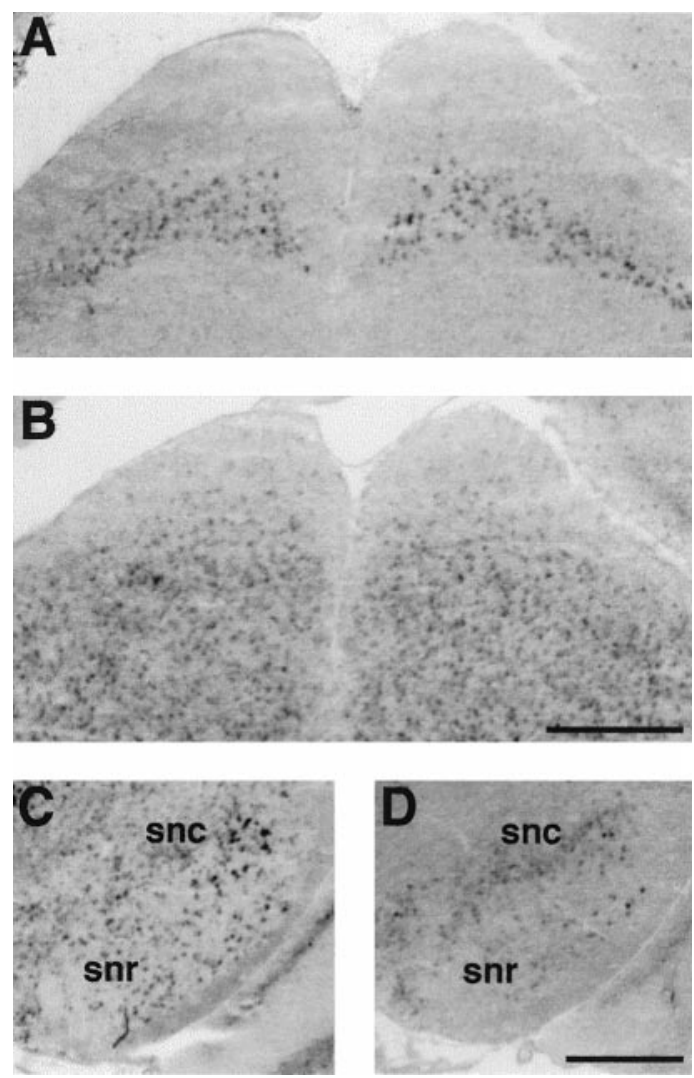

Figure 5. Expression of $\mathrm{mHCN} 1, \mathrm{mHCN} 2$, and $\mathrm{mHCN} 4$ transcripts in midbrain. $A$, Coronal section (bregma, -4.04) showing mHCN1 labeling in the superior colliculus. $B, \mathrm{mHCN} 2$ labeling in the superior colliculus. $C$, Coronal section (bregma, -3.28) showing staining for mHCN2 in substantia nigra, pars reticulata $(s n r)$. $D$, Staining for mHCN4 in substantia nigra, mostly pars compacta $(s n c)$. Scale bars, $500 \mu \mathrm{m}$.

\section{Brainstem and spinal cord}

The highest levels of $\mathrm{mHCN} 2$ expression in the CNS are found in the brainstem and this strong staining extends into the spinal cord (Fig. $7 B, D, F$ ). All areas within these structures contain cells that are strongly labeled for mHCN2 transcripts, with the notable exception of the inferior olive, which exhibits only a low amount of staining (Fig. 7D). Labeling for $\mathrm{mHCN} 2$ is often accompanied by a low level of mHCN4 staining (data not shown). In contrast, $\mathrm{mHCN} 1$ probes display a strikingly restricted pattern of labeling, with strong staining seen in selected nuclei (Fig. $7 A, C, E$ ). High levels of $\mathrm{mHCN} 1$ expression are found in the ventral cochlear nucleus and spinal trigeminal nucleus (Fig. $7 A$ ), as well as in the motor nuclei of the facial (Fig. 7A) and hypoglossal (Fig. 7C) cranial nerves, and in the $\alpha$-motorneurons of the ventral horn of the spinal cord (Fig. 7E).

\section{Different neurons display $I_{\mathrm{h}}$ currents with diverse biophysical properties}

Given the differential and complementary staining pattern of mHCN transcripts in different neurons within certain brain regions, we next investigated whether there was a similar heterogeneity in the functional properties of $I_{\mathrm{h}}$ currents in these cells as determined using whole-cell recordings. In addition, given the marked difference in the properties of recombinant mHCN1, 2, and 4 channels expressed in heterologous cells as previously reported by different investigators and further delineated below, we also were interested in whether there was any correlation between channel properties in native cells and the properties expected based on mRNA expression.
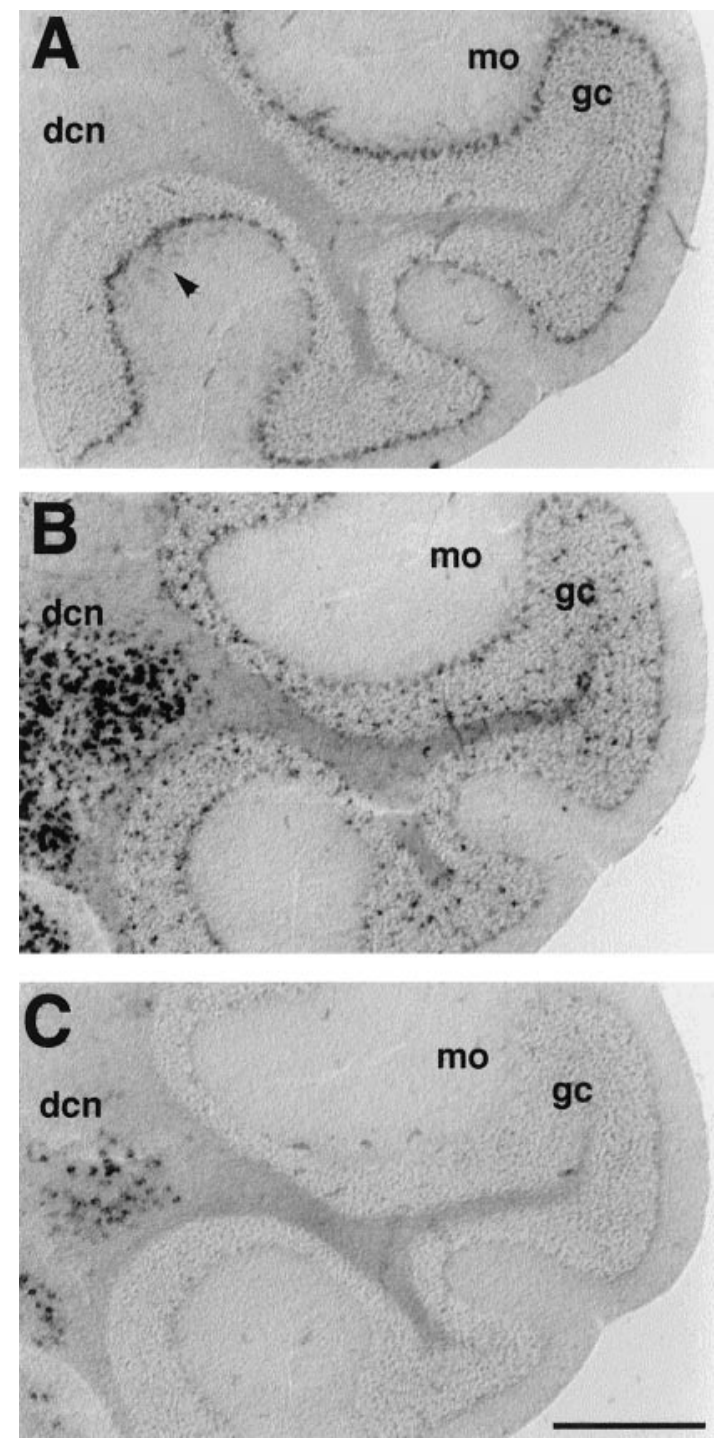

Figure 6. Differential expression of mHCN1, mHCN2, and mHCN4 transcripts in cerebellum. $A$, Coronal section (bregma, -6.24) showing labeling of Purkinje cells by mHCN1 probe. Weak labeling of basket cells (arrowheads) is also visible in the molecular layer $(m o)$. B, Labeling of Purkinje cell layer, granule cell layer $(g c)$, and deep cerebellar nuclei $(d c n)$ by mHCN2 probe. $C, \mathrm{mHCN} 4$ labeling in deep cerebellar nuclei. Scale bar, $500 \mu \mathrm{m}$.

\section{Biophysical properties of recombinant $m H C N 1$ and mHCN2 channels}

We first determined the kinetics and steady-state activation properties for recombinant mouse $\mathrm{mHCN} 1$ and $\mathrm{mHCN} 2$ channels expressed in Xenopus oocytes. Although we had previously reported on activation parameters of mHCN1 channels expressed in Xenopus oocytes using cell-free patches (Santoro et al., 1998) and others had reported on $\mathrm{mHCN} 2$ channel properties using whole-cell recordings from mammalian cell lines (Ludwig et al., 1998), changes in the local environment can exert a marked effect on the kinetics and steady-state voltage dependence of $I_{\mathrm{h}}$. For example, submicromolar concentrations of cAMP, patch excision, or whole-cell dialysis affect the kinetics and voltage dependence of $I_{\mathrm{h}}$ (DiFrancesco and Mangoni, 1994) (G. R. Tibbs, B. Santoro, and S. A. Siegelbaum, unpublished data). Thus, experimental differences between different laboratories could conceivably contribute to differences in reported channel properties. We have therefore reexamined the kinetics and steady-state activation properties of mHCN1 and mHCN2 channels recorded under identical conditions using a two microelectrode voltage-clamp of Xenopus oocytes so as not to perturb the intracellular environment. 

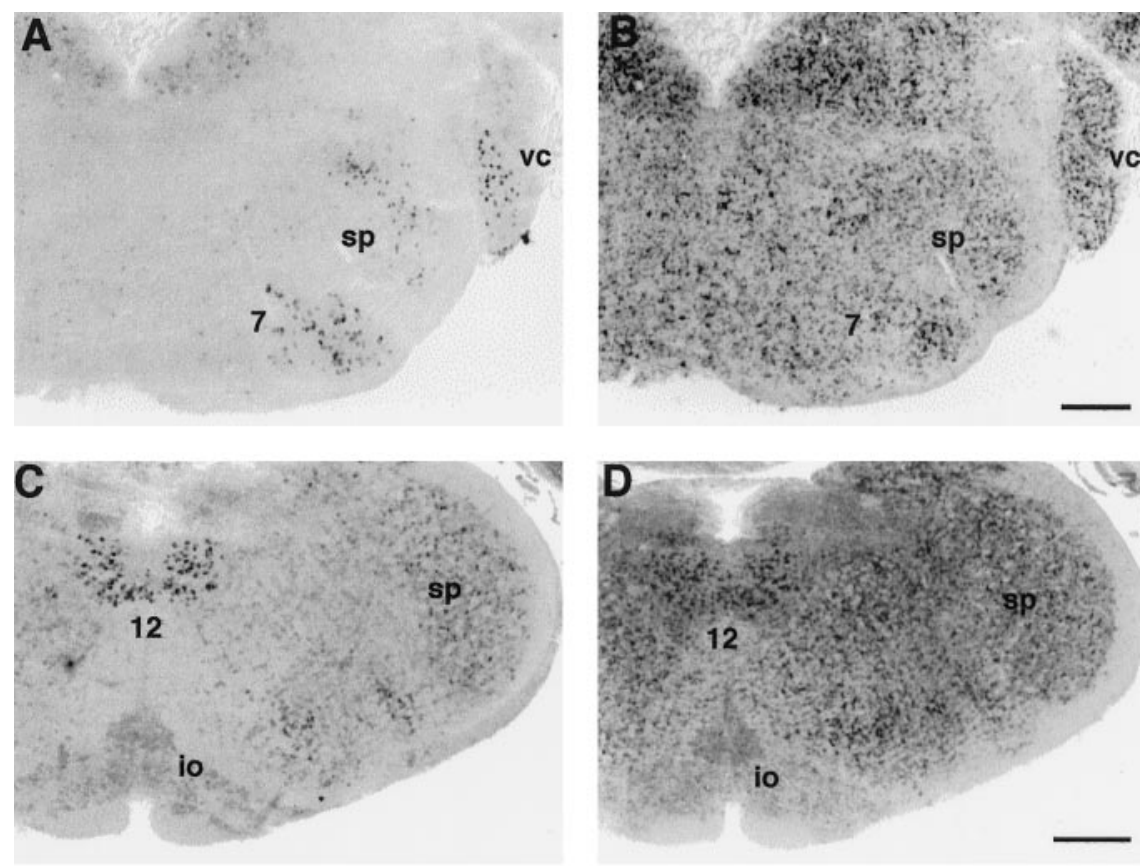

Figure 7. mHCN1 is expressed in selected nuclei in the brainstem and spinal cord. $A$, Coronal section (bregma, -6.24) showing labeling of ventral cochlear nucleus $(v c)$, spinal trigeminal nucleus $(s p)$, and facial nucleus (7) by $\mathrm{mHCN} 1$ probe. Weak labeling of vestibular nuclei is also visible. $B$, Serial section showing labeling by mHCN2 probe. $C$, Coronal section (bregma, -7.08) showing labeling of hypoglossal nucleus (12) by mHCN1 probe. Weak labeling of spinal trigeminal and lateral reticular nuclei, as well as of inferior olive (io) is also visible. $D$, Serial section showing labeling by mHCN2 probe. E, Coronal section through thoracic spinal cord showing labeling by $\mathrm{mHCN} 1$ probe; notice strong labeling of the motorneurons in the ventral horn (arrowhead). F, Serial section showing labeling by mHCN2 probe. Scale bars, $500 \mu \mathrm{m}$.
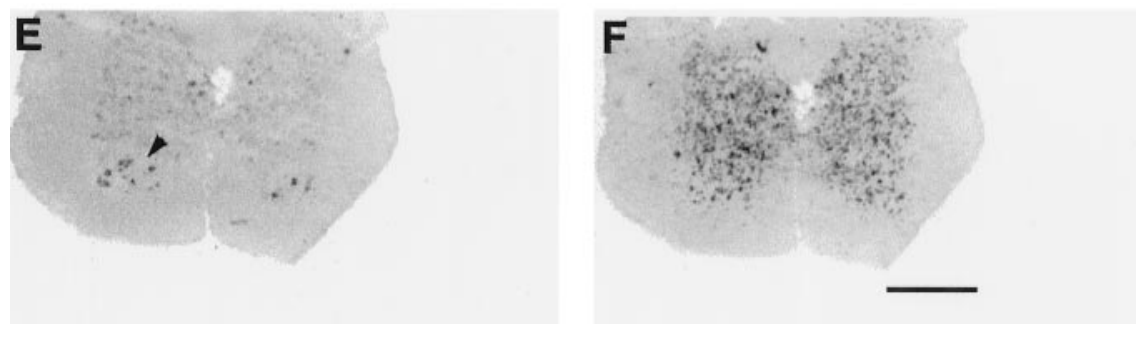

Recombinant mHCN1 and mHCN2 channels clearly display distinct kinetics of activation in response to hyperpolarizing voltage-clamp steps (Fig. 8). The mHCN2 currents show a distinct, sigmoidal onset of activation after the hyperpolarizing step, contributing an apparent delay. In contrast, mHCN1 currents show a much less pronounced delay in their onset of activation. Even after the initial delay, mHCN2 currents activate with a much slower time course compared to mHCN1 currents (Fig. 8A). The kinetics of mHCN1 and mHNC2 current activation after the initial delay have been previously described by single exponential functions (Ludwig et al., 1998; Santoro et al., 1998). However, fits with two exponential components (after the initial lag) provide a more accurate description of the kinetics of both mHCN1 (Fig. 8B1) and mHCN2 (Fig. 8B2) currents. For each $\mathrm{mHCN}$ isoform, the fast time constant is $\sim 5$ - to 10 -fold more rapid than the slow time constant of activation, with both fast and slow components becoming more rapid with steps to more hyperpolarized potentials (Fig. 9A). Over the entire voltage range of activation, the fast and slow time constants of activation for $\mathrm{mHCN} 1$ are approximately 10 -fold faster than the respective time constants for $\mathrm{mHCN} 2$. Moreover, for $\mathrm{mHCN} 1$, the fast component of activation accounts for the majority of the current amplitude over the entire voltage range, representing $70-90 \%$ of the total current amplitude relative to the slow component (Fig. 9B). In contrast, for mHCN2, the slow component is predominant for voltage steps to potentials near the midpoint for current activation. With steps to more hyperpolarized voltages, the contribution of the slow component rapidly diminishes, and the fast component becomes predominant (Fig. 9B).

To determine how the extent of $I_{\mathrm{h}}$ activation depends on voltage, we measured tail current amplitudes at a fixed membrane potential $(-40 \mathrm{mV})$ after hyperpolarizing voltage steps to different test potentials. The duration of the hyperpolarization was varied between 0.1 and $30 \mathrm{sec}$ to determine the length of time required for activation to approach its steady-state value. Activation curves were then fit by a Boltzmann distribution to determine the midpoint voltage of activation $\left(V_{1 / 2}\right)$ as well as the slopes of the relation (see Materials and Methods). Both mHCN1 and mHCN2 channels display typical S-shaped activation curves after hyperpolarization (Fig. 9C). However, the midpoint activation of $\mathrm{mHCN} 1(-71.6 \pm$ $1.0 \mathrm{mV} ; n=8)$ is $\sim 7 \mathrm{mV}$ more positive than the value for $\mathrm{mHCN} 2$ $(-78.3 \pm 0.8 \mathrm{mV} ; n=3)$. These values for both mHCN1 and $\mathrm{mHCN} 2$ are $30-40 \mathrm{mV}$ more positive than the initial reported values (Ludwig et al., 1998; Santoro et al., 1998). This discrepancy is attributable to negative shifts in steady-state activation curves associated with patch excision and whole-cell dialysis (DiFrancesco and Mangoni, 1994) (Tibbs, Santoro, and Siegelbaum, unpublished data). Estimates of the $V_{1 / 2}$ in previous studies may have also been shifted to negative voltages by the use of relatively brief hyperpolarizing test pulses that do not permit activation to approach steady-state values. A plot of $V_{1 / 2}$ as a function of test pulse duration clearly shows the time dependence of this parameter which, because of the differences in kinetics between mHCN1 and mHCN2, is distinct for $\mathrm{mHCN} 1$ and $\mathrm{mHCN} 2$ (Fig. 9D). Test pulses of $3 \mathrm{sec}$ in duration are evidently sufficient for mHCN1 to reach equilibrium, whereas even $30 \mathrm{sec}$ test pulses may not be sufficient for $\mathrm{mHCN} 2$ to reach its equilibrium condition.

Because of the voltage dependence of activation kinetics, we have compared the time constants of activation of recombinant $\mathrm{mHCN}$ channel isoforms at a fixed voltage of $-105 \mathrm{mV}$, at the peak of the activation curve. The mean fast and slow time constants for mHCN1, determined from the biexponential fits, were $79 \pm 9$ and $339 \pm 47 \mathrm{msec}$, respectively, with the fast component accounting for $76 \pm 4 \%$ of the amplitude. For mHCN2 channels, the kinetics of the fast component of activation were approximately eightfold slower than those of mHCN1, with a time constant of $591 \pm 8 \mathrm{msec}$. The slow component of $\mathrm{mHCN} 2$ was $\sim 12$-fold slower than that of mHCN1, with a time constant of $4970 \pm 540 \mathrm{msec}$, with the fast component accounting for $89 \pm 3 \%$ of the amplitude. We have also 
A1
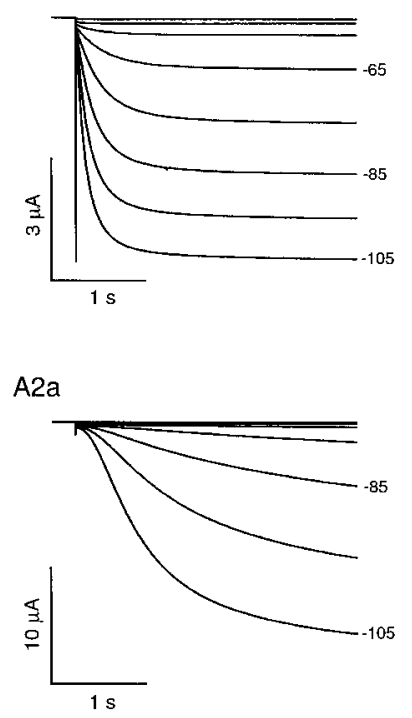

$\mathrm{A} 2 \mathrm{~b}$

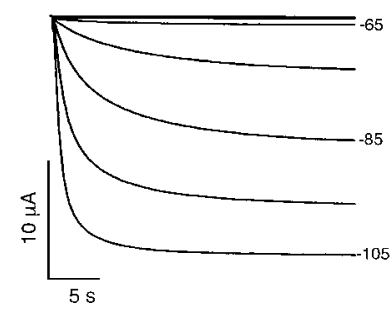

B1

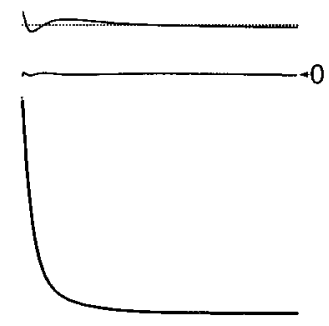

$\mathrm{B} 2 \mathrm{a}$

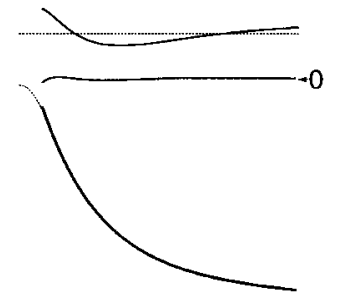

$\mathrm{B} 2 \mathrm{~b}$

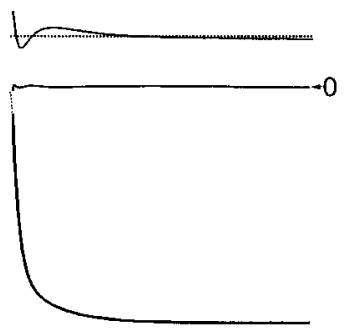

Figure 8. Distinct functional properties of $I_{\mathrm{h}}$ currents generated by mHCN1 and mHCN2. $A$, Currents generated in response to hyperpolarizing voltage steps in Xenopus oocytes expressing mHCN1 (A1) or mHCN2 $(A 2)$, respectively. $A 1, \mathrm{mHCN} 1$ currents shown during 3-sec-long hyperpolarizing voltage steps. $A 2 a, b, \mathrm{mHCN} 2$ currents shown during initial $3 \mathrm{sec}$ $(A 2 a)$ and entire $30 \mathrm{sec}$ time course $(A 2 b)$ in response to hyperpolarizing voltage steps. For both $A 1$ and $A 2$, membrane held at $-30 \mathrm{mV}$ and stepped from -35 to $-105 \mathrm{mV}$ in $10 \mathrm{mV}$ increments (selected voltages indicated to right of current traces). $B$, Two exponential components are required to adequately fit activation time course of mHCN currents. Time and current scales as in corresponding panels in $A$. For $B 1$ and $B 2$, bottom traces show current during hyperpolarizing step to $-105 \mathrm{mV}$ with superimposed fit using two exponential components. The middle and top traces show the residuals of difference between the recorded current and the fitted single (top trace) or double (middle trace) exponential functions. Zero current is indicated by the arrowhead (labeled 0 ). The residuals from the single exponential fits are displaced from zero for clarity; zero current for these traces is indicated by the dashed line. To facilitate comparison between $\mathrm{mHCN} 1$ and $\mathrm{mHCN} 2$, the first $3 \mathrm{sec}$ of the $\mathrm{mHCN} 2$ activation time course and fits to this are shown on an expanded time scale in $B 2 a$.

approximated the time course of activation of the recombinant channels using single exponential fits, to allow comparison with previous studies. In these fits, $\mathrm{mHCN} 1$ channels activate with a time constant of $125 \pm 12.6 \mathrm{msec}(n=8)$, whereas mHCN2 channels activate with a time constant of $1194 \pm 276 \mathrm{msec}(n=3)$.

\section{Native $\mathrm{I}_{h}$ currents in thalamus and hippocampus}

Given the marked differences in kinetics of the $\mathrm{mHCN}$ isoforms and distinct patterns of gene expression, we next examined the biophysical properties of native $I_{\mathrm{h}}$ currents in some detail. Our analysis first focused on the thalamus, a region that presents strong expression of $\mathrm{mHCN}$ transcripts. Although previous studies have characterized $I_{\mathrm{h}}$ currents from thalamic neurons in other species (McCormick and Pape, 1990; Williams et al., 1997), no detailed studies have been reported for mice, the species in which we characterized mHCN mRNA expression patterns. We measured currents during hyperpolarizing voltage-clamp steps from both

A

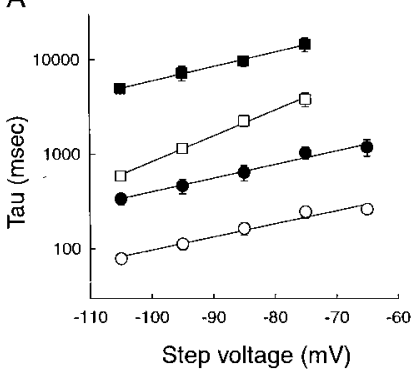

C
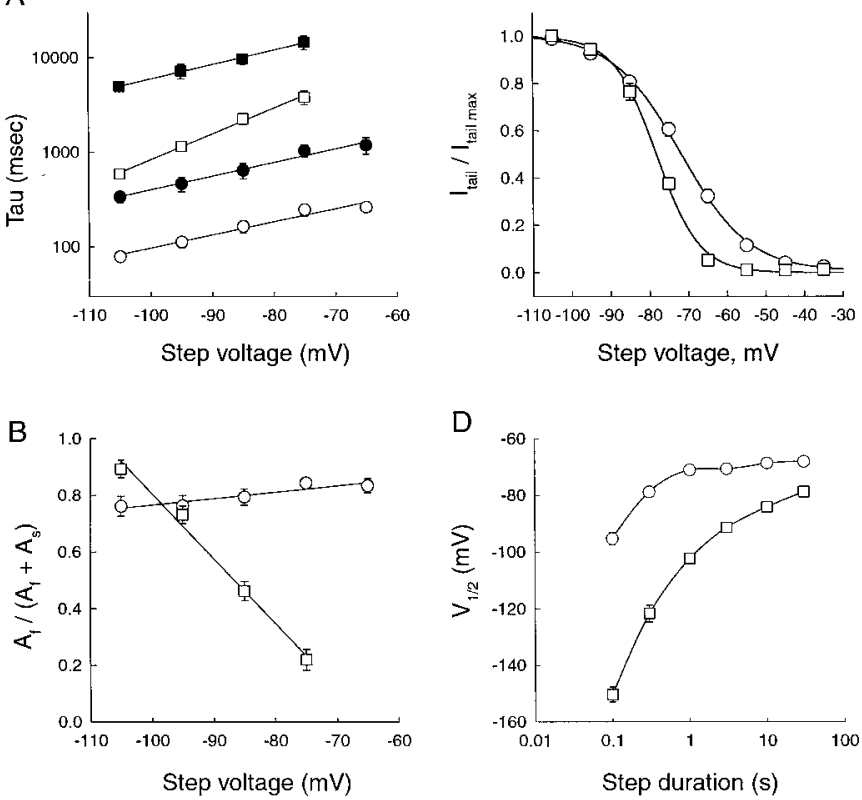

Figure 9. Comparison of kinetic and steady-state activation properties between mHCN1 and mHCN2. A, Fast (open symbols) and slow (filled symbols) exponential time constants as function of voltage during hyperpolarizing step. For all panels: circles, mHCN1; squares, mHCN2. B, Relative amplitude of fast exponential component as function of hyperpolarizing voltage step. $\mathrm{A}_{\mathrm{f}}$ and $A_{s}$ are the amplitudes of the fast and slow exponential components, respectively. $C$, Steady-state tail current activation curves obtained using $30 \mathrm{sec}$ hyperpolarizing steps for mHCN2 channels and $3 \mathrm{sec}$ steps for mHCN1 channels. Curves fit with Boltzmann relation (see Materials and Methods for details). $D$, Relation between values of $V_{1 / 2}$ determined from activation curves using hyperpolarizing steps of different durations for $\mathrm{mHCN} 1$ and $\mathrm{mHCN} 2$ channels.

thalamocortical relay neurons, which express mHCN2 and mHCN4 transcripts at high levels, and neurons from the nucleus reticularis, an area of the thalamus that displays labeling for $\mathrm{mHCN} 2$, but no detectable labeling for mHCN4 (Fig. 4A,B). Consistent with recordings from thalamic neurons in guinea pig and cat (McCormick and Pape, 1990; Williams et al., 1997), principal relay neurons of the mouse thalamus display very large hyperpolarization-activated currents (1000-2000 pA at $-103 \mathrm{mV}$; Fig. 10A, left traces), which activate with distinctly slow kinetics after an initial pronounced sigmoidal lag. Indeed, for voltage steps near the threshold for $I_{\mathrm{h}}$ activation, steady-state activation is reached only after tens of seconds.

In contrast to the thalamocortical relay neurons, we detected no $I_{\mathrm{h}}$ currents in recordings from five separate neurons from the reticular nucleus (Fig. 10A, right traces). Hyperpolarizing steps to $-103 \mathrm{mV}$ failed to activate any time-dependent inward current. This lack of current is surprising, given the prominent expression of $\mathrm{mHCN} 2$ in this cell type (Fig. $4 A$ ).

The second brain region that we examined was the hippocampus, where in situ hybridization revealed distinct patterns of mHCN1, 2, and 4 labeling in CA1 and CA3 pyramidal neurons and stratum oriens and stratum radiatum/lacunosum-moleculare interneurons (Fig. 3). Whole-cell recordings were performed on each of these neuronal cell types, and current traces in response to hyperpolarizing voltage steps are shown for representative cells in Figure $10 \mathrm{~B}$. It is apparent that the different types of neurons display markedly different $I_{\mathrm{h}}$ current magnitudes, albeit never as high as found in the relay cells of the thalamus (Fig. 10C). Thus, CA1 pyramidal cells and stratum oriens interneurons display moderately large $I_{\mathrm{h}}$ currents $(100-400 \mathrm{pA}$ at $-103 \mathrm{mV})$, whereas CA1 and CA3 stratum radiatum interneurons revealed smaller, but reproducible levels of $I_{\mathrm{h}}(\sim 100 \mathrm{pA})$. The time course of $I_{\mathrm{h}}$ activation in the hippocampal neurons was generally more rapid than that seen in the thalamus. In 
A

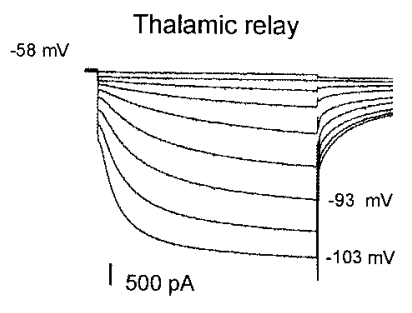

B
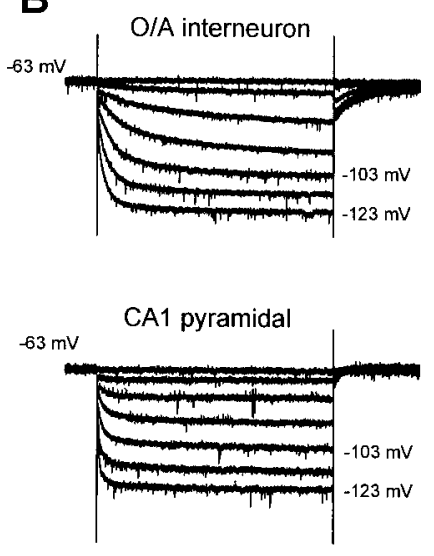

C

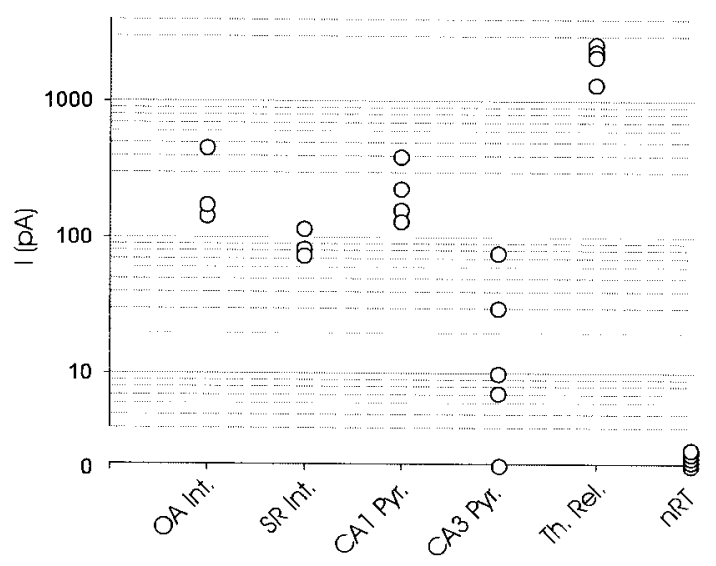

Figure 10. Differential functional properties of $I_{\mathrm{h}}$ in thalamic and hippocampal neurons as assessed by whole-cell patch-clamp recordings. $A$, Current recording from a thalamocortical relay cell from the ventral posterior nucleus (left) and from a nucleus reticularis neuron (right). Holding potential was $-58 \mathrm{mV}$, and the voltage was stepped to negative potentials for $2.8 \mathrm{sec}$ in $5 \mathrm{mV}$ increments to $-103 \mathrm{mV}$. Scale bars as indicated or as in $B$ for time. B, Recordings from hippocampal neurons. Top left, Stratum oriens/alveus $(O / A)$ interneuron; top right, stratum radiatum $(S R)$ interneuron; bottom left, CA1 pyramidal neuron; bottom right, CA3 pyramidal neuron. In each case, the holding potential was -63 , and the voltage was stepped to negative potentials for $3 \mathrm{sec}$ in $10 \mathrm{mV}$ increments down to -123 $\mathrm{mV}$. Calibration: $200 \mathrm{pA}, 0.5 \mathrm{sec}$. $C$, Comparison of peak current in the six cell types shown in $A$ and $B$. Each point is an individual experiment. The $I_{\mathrm{h}}$ current at the end of 2.8 - to 3 -sec-long voltage steps to $-103 \mathrm{mV}$ was measured as the difference between the net current record and the leakage current, measured from the initial current level after the capacitative transient at the beginning of each voltage step.

particular, $I_{\mathrm{h}}$ in CA1 pyramidal neurons activates very rapidly and with little initial lag. Surprisingly, despite the presence of high levels of mHCN1 and mHCN2 transcripts, CA3 pyramidal neurons showed either only very small $I_{\mathrm{h}}$ currents $(<100 \mathrm{pA}$; two of five cells) or no detectable $I_{\mathrm{h}}(<10 \mathrm{pA}$; three of five cells; Fig. 10B,C).

These data from the thalamus and the hippocampus suggest that
A
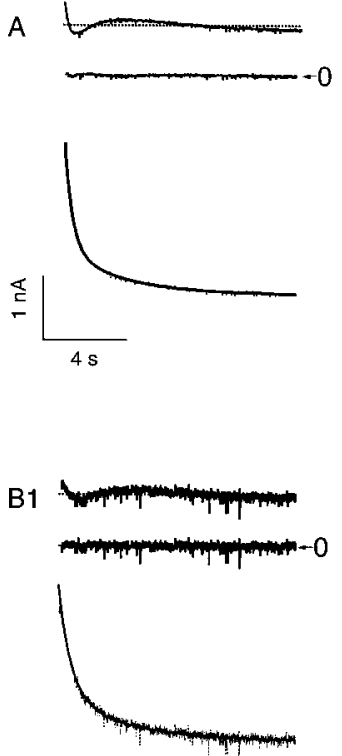

$\mathrm{B} 2$
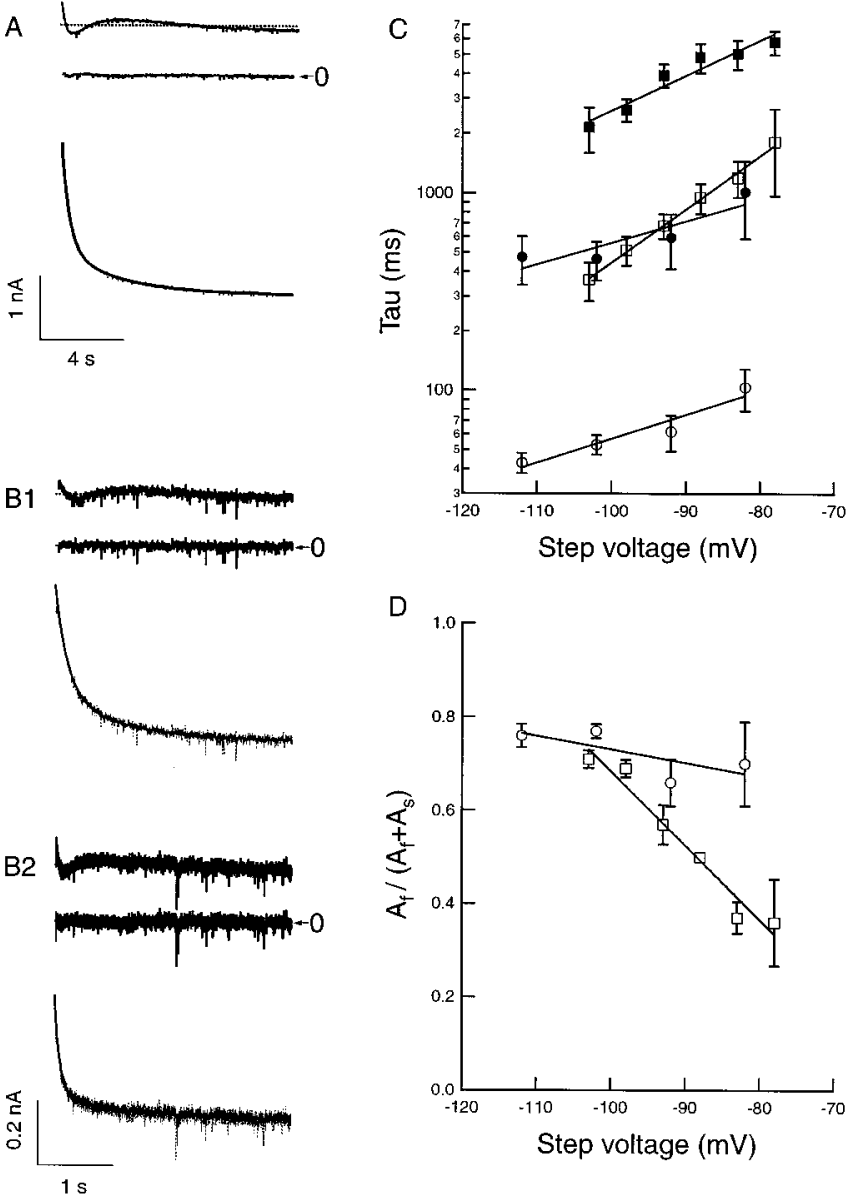

D

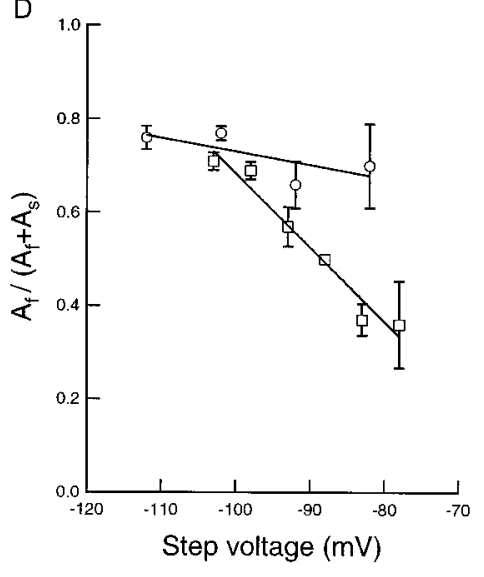

Figure 11. Comparison of biexponential activation kinetics of $I_{\mathrm{h}}$ current in native neurons. $A, B$, Double exponential fit of current traces for thalamic relay neuron $(A)$, hippocampal OA interneuron $(B 1)$, and hippocampal CA1 pyramidal neuron $(B 2)$ during hyperpolarizing voltage step to -103 $\mathrm{mV}$. Step length was $11.2 \mathrm{sec}$ for thalamocortical relay cell and $3 \mathrm{sec}$ for hippocampal cells. From bottom, traces show superimposed currents and biexponential fits, residuals from biexponential fits, and residuals from single exponential fits. C, "Fast" (open symbols) and "slow" ( filled symbols) time constants of activation as function of voltage for thalamic relay neurons (squares) and hippocampal CA1 pyramidal neurons (circles); $n=4$. $D$, Relative amplitude of the fast exponential component as function of voltage. Circles, Hippocampal CA1 neurons. Squares, Thalamic relay neurons.

the simple presence of an mHCN channel transcript in a cell is not a reliable predictor of significant functional expression of the channel, at least within compartments that are electrically accessible to somatic whole-cell recording. It should be noted that the lack of current in nucleus reticularis and CA3 pyramidal neurons was not attributable to the poor health of those particular slices. In several experiments, robust $I_{\mathrm{h}}$ currents could be measured in either thalamic relay cells or CA1 pyramidal neurons from the same slices in which either nucleus reticularis or CA3 pyramidal neurons were found to lack detectable $I_{\mathrm{h}}$.

We next asked, for those cells where $\mathrm{mHCN}$ transcripts were present and $I_{\mathrm{h}}$ was detected, whether there is any correlation between the pattern of isoform expression and the biophysical parameters of $I_{\mathrm{h}}$ activation predicted from the properties of the recombinant channels. Although the $V_{1 / 2}$ for activation of thalamocortical relay neurons $(-82 \pm 1.5 \mathrm{mV})$ is similar to that observed in hippocampal neurons (approximately $-85 \mathrm{mV}$ ), the kinetics of $I_{\mathrm{h}}$ activation are markedly different. The activation time course of $I_{\mathrm{h}}$ currents for both thalamic (Fig. 11A) and hippocampal (Fig. $11 B$ ) neurons requires two exponential components (after an initial lag), whose time constants decrease as the membrane test voltage becomes more negative (Fig. 11C). Over the entire voltage 


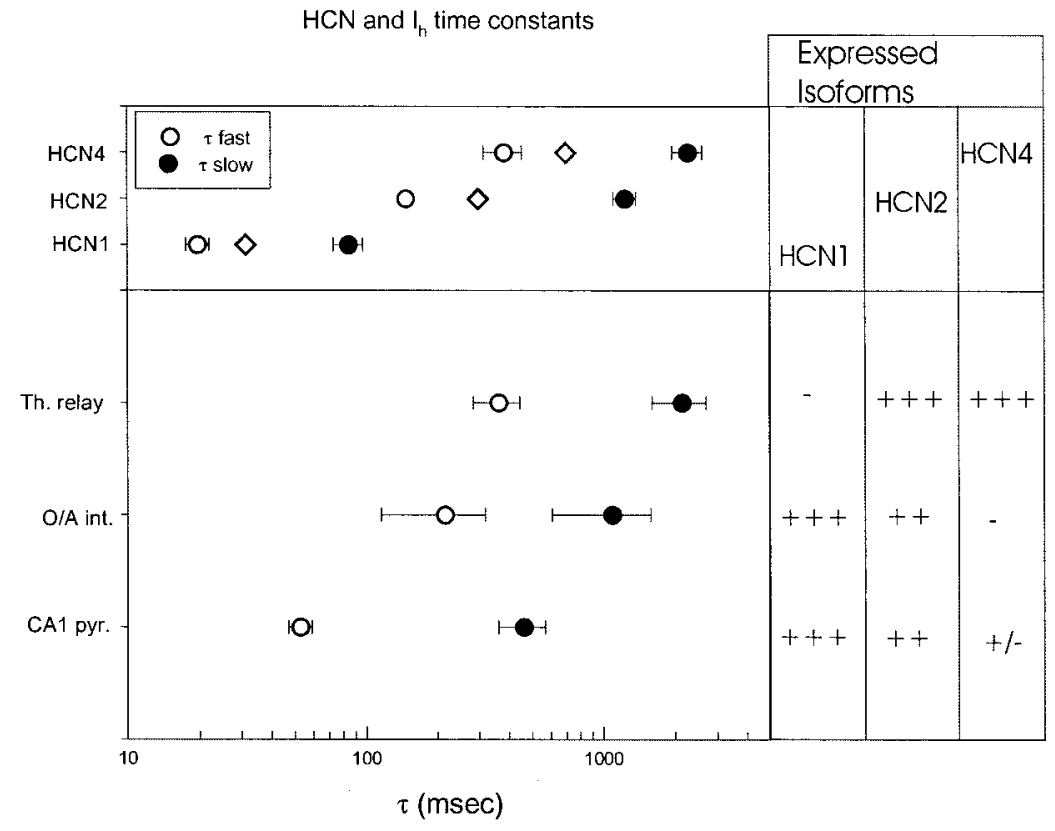

Figure 12. Summary comparing HCN isoform mRNA expression with time constants of activation for recombinant HCN isoforms and native $I_{\mathrm{h}}$ currents. Top, Fast (open circles) and slow ( filled circles) exponential time constants of activation for different $\mathrm{HCN}$ isoforms from biexponential fits during voltage step to $-105 \mathrm{mV}$. Diamonds show time constants from single exponential fits, reflecting predominant fast component. Bottom, Fast and slow exponential time constants for $I_{\mathrm{h}}$ in thalamocortical relay neurons, hippocampal $\mathrm{O} / \mathrm{A}$ interneurons, and hippocampal CA1 pyramidal neurons. Data show mean \pm $\mathrm{SE}$ for fast and slow components. Panel on right summarizes relative expression levels for mHCN1, 2, and 4 mRNA. Data for HCN4: circles, at $-110 \mathrm{mV}$ and $35^{\circ} \mathrm{C}$ (Ishii et al., 1999); diamonds, extrapolated to $-105 \mathrm{mV}$ (Seifert et al., 1999) and scaled to $34^{\circ} \mathrm{C}$. range, the fast and slow exponential components for hippocampal pyramidal neurons are $\sim 10$-fold more rapid than the respective fast and slow exponential components for the thalamic relay neurons. In the thalamic relay cells, the slow component of $I_{\mathrm{h}}$ activation is predominant with voltage steps to the middle of the activation range. However, with steps to more hyperpolarized potentials, the relative contribution from the fast component increases (Fig. 11D). In contrast, in hippocampal CA1 neurons the fast component is predominant over the entire activation voltage range (Fig. 11D).

\section{Comparison of $\mathrm{I}_{h}$ kinetics for native and recombinant channels}

In Figure 12, we compare the activation kinetics of recombinant and native $I_{\mathrm{h}}$ currents. Because of the voltage dependence of channel activation, we determined time constants of $I_{\mathrm{h}}$ at a fixed membrane potential of $-103 \mathrm{mV}$, similar to that used to study recombinant $I_{\mathrm{h}}$ kinetics $(-105 \mathrm{mV}$; the slight difference, arising from junction potentials, does not significantly affect the comparison; see Figs. 9, 11). For thalamic relay cells, the mean time constants of activation were $364 \pm 81 \mathrm{msec}$ and $2.14 \pm 0.55 \mathrm{sec}$ with the fast component accounting for $71 \pm 1.9 \%$ of the amplitude $(n=$ 4). In CA1 pyramidal neurons, the mean time constants for activation were $53 \pm 6 \mathrm{msec}$ and $464 \pm 103 \mathrm{msec}$ with the fast component representing $77 \pm 1.5 \%$ of the amplitude $(n=4)$. For stratum oriens interneurons, the mean time constants of activation $(216 \pm$ $101 \mathrm{msec}$ and $1084 \pm 487 \mathrm{msec}$ with $59 \pm 5.5 \%$ fast component; $n=$ 3 ) fall between those of the CA1 pyramidal and thalamic relay cells.

To compare the native $I_{\mathrm{h}}$ kinetics, determined at $34^{\circ} \mathrm{C}$, with the $\mathrm{mHCN} 1$ and $\mathrm{mHCN} 2 I_{\mathrm{h}}$ kinetics, studied at $23-25^{\circ} \mathrm{C}$, we have scaled the recombinant kinetics using a $\mathrm{Q}_{10}$ of 4 (Santoro and Tibbs, 1999). Although we have not succeeded in expressing fulllength mouse HCN4, rabbit (Ishii et al., 1999) and human (Seifert et al., 1999) HCN4 have been expressed and studied in mammalian cell lines. HCN4 activates even more slowly than mHCN2. Seifert et al. (1999) report a single exponential time constant of activation for human HCN4, whereas Ishii et al. (1999) report two exponential components of activation for rabbit HCN4. The kinetic data for HCN4 (at $34-35^{\circ} \mathrm{C}$ ) are plotted with our data for mHCN1 and mHCN2 in Figure 12 (top panel), and compared to native $I_{\mathrm{h}}$ kinetics (bottom panel). The implications of these comparisons are discussed below.

\section{DISCUSSION}

The results presented above, together with data from a number of previous studies (Santoro et al., 1997; Ludwig et al., 1998; Moos- mang et al., 1999), indicate that each mHCN channel isoform has a unique distribution within the CNS. The distribution of $\mathrm{mHCN}$ isoforms is associated with differences in $I_{\mathrm{h}}$ kinetics recorded from different brain regions. Comparison of isoform expression patterns with the kinetic properties of recombinant mHCN channel currents suggests a potential molecular basis for the heterogeneity in native $I_{\mathrm{h}}$ channel properties.

We find that mHCN1 currents show the fastest kinetics, mHCN2 currents show intermediate kinetics, and HCN4 channels show the slowest kinetics. In native cells, hippocampal CA1 neurons, which express high levels of $\mathrm{mHCN} 1$ and somewhat lower levels of mHCN2, show very rapid kinetics. Thalamic relay cells, which express $\mathrm{mHCN} 2$ and $\mathrm{mHCN} 4$, show very slow kinetics. Moreover, the kinetics of activation of $I_{\mathrm{h}}$ in CA1 neurons span the time scale of activation of $\mathrm{mHCN} 1$ and $\mathrm{mHCN} 2$, whereas the kinetics of $I_{\mathrm{h}}$ activation in thalamic relay neurons span the time scale of activation of mHCN2 and HCN4. Therefore, it appears likely that at least some of the differences in kinetics among neuronal types reflect the differential expression of $\mathrm{mHCN}$ isoforms in the different neuronal types. Such comparisons, however, may be complicated by differences in posttranslational modification between native neurons and heterologous expression systems, potential formation of heteromultimeric $\mathrm{mHCN}$ channels, and subtle differences in recording conditions in the two types of experiments. Finally, because homomeric recombinant HCN channels display biexponential activation kinetics, the biexponential kinetics of $I_{\mathrm{h}}$ in native neurons does not necessarily imply the expression of two different HCN isoforms. Thus, the biexponential kinetics of $I_{\mathrm{h}}$ currents measured in CA1 pyramidal neurons or in thalamocortical relay cells could reflect the biexponential kinetics of a uniform population of channels composed of a single $\mathrm{HCN}$ isoform (i.e., mHCN1 for pyramidal and mHCN4 for thalamic neurons). Alternatively, the native kinetics could reflect coexpression of $\mathrm{mHCN} 1$ channels and mHCN2 channels for CA1 neurons or mHCN2 channels and mHCN4 channels for thalamic relay neurons. Definitive proof as to the role of specific $\mathrm{mHCN}$ isoforms in determining native $I_{\mathrm{h}}$ properties will have to await studies in mutant mice with deletions in specific mHCN genes.

Because we have not performed co-staining for expression of different isoforms in a single section, we also cannot definitively conclude whether multiple isoforms are indeed expressed in a single cell. However, the high levels of uniform staining for mHCN1 and mHCN2 in the hippocampal pyramidal CA1 and CA3 layers and for $\mathrm{mHCN} 2$ and $\mathrm{mHCN} 4$ in thalamocortical relay nuclei 
strongly suggest that multiple isoforms are likely to be expressed in the same cells. In contrast, the low density of the stratum oriens and stratum radiatum interneurons and resultant sparse punctate mRNA staining patterns for $\mathrm{mHCN} 1$ and $\mathrm{mHCN} 2$ isoforms make it difficult to determine whether any single interneuron expresses both isoforms.

It is puzzling why certain cells express mHCN mRNA at high levels but do not exhibit detectable $I_{\mathrm{h}}$-type currents. For example, hippocampal CA3 pyramidal cells display significant levels of all three $\mathrm{mHCN}$ transcripts (Fig. 3), yet little or no $I_{\mathrm{h}}$ current is recorded (Fig. 10). Similarly, thalamic reticular cells, which express mHCN2 transcripts (Fig. 4), do not appear to exhibit any native $I_{\mathrm{h}}$ currents (Fig. 10). It is possible that $\mathrm{mHCN}$ channels are targeted to distal regions of the cell that are electrically remote from the cell body, where our recordings were performed. Indeed, we know that the $\mathrm{mHCN} 1$ protein can be localized to the distal ends of dendritic and axonal processes (Nicoll et al., 1993; Santoro et al., 1997; Magee, 1998, 1999; Stuart and Spruston, 1998). It is also possible that certain mHCN mRNA is not stably translated or that the mHCN channels are present but functionally inactivated. This latter view is consistent with findings in adult cardiac ventricular muscle (Yu et al., 1993; Robinson et al., 1997), in which the threshold of activation of $I_{\mathrm{h}}$ is shifted to very negative potentials that are not reached during typical whole-cell recordings.

\section{Physiological function of $\mathrm{mHCN}$ isoforms}

Can we associate any particular $\mathrm{mHCN}$ isoform with a specific physiological function, based on the observed patterns of distributions? On a general note, whereas $\mathrm{mHCN} 2$ has a very widespread distribution in the brain, $\mathrm{mHCN} 1$ and $\mathrm{mHCN} 4$ show predominantly cortical and subcortical distributions, respectively. Thus, mHCN1 is most abundant in the cerebral, hippocampal, and cerebellar cortices, whereas mHCN4 is primarily expressed in the thalamus. mHCN4 is also expressed, together with mHCN2, throughout the basal ganglia and in the deep cerebellar nuclei, structures in which mHCN1 is absent. As a consequence, there is very little overlap in the localization of the fastest (mHCN1) and slowest (mHCN4) of the mHCN channel isoforms. Nevertheless, all combinations occasionally do occur in different parts of the brain, including each isoform being expressed alone (e.g., mHCN1 in cerebellar basket cells, mHCN2 in thalamic reticular nucleus cells, and mHCN4 in medial habenula). The latter observation is consistent with the idea that the mHCN subunits can be expressed as homomeric channels in vivo. A determination of the specific subcellular patterns of $\mathrm{mHCN}$ protein localization within neurons containing multiple mHCN transcripts will help establish whether the $I_{\mathrm{h}}$ channels may assemble as heteromultimers under physiological conditions.

One interesting recurrent finding is the presence of high levels of mHCN1 transcripts in large, principal, output neurons that display extensive dendritic arborizations and often have far-reaching axons. Such cells include the layer V pyramidal neurons in the cerebral cortex, the motorneurons of the cranial and spinal nerves, as well as the Purkinje neurons in the cerebellar cortex. Superior colliculus neurons of the intermediate gray layer may also fall into this category. A potential functional role for this pattern of expression is suggested by the finding that $I_{\mathrm{h}}$ channels are distributed along a gradient in the apical dendrites of pyramidal cells, being present at higher density at increasing distances from the soma, and are important for the regulation of signal integration and propagation along the dendrosomatic axis (Nicoll et al., 1993; Magee, 1998, 1999; Stuart and Spruston, 1998). This might be an important feature of $I_{\mathrm{h}}$ channels in principal neurons, which have to integrate numerous incoming signals on a spatially extended field. The mHCN1 channels, by virtue of their rapid kinetics, would be better suited to rapidly activate during fast IPSPs and EPSPs and shape the postsynaptic response.

Another cell population in which $\mathrm{mHCN} 1$ appears consistently in different brain regions is basket cells, in which anti-mHCN1 antibody labeling suggests that the channel is confined to axon terminals (Santoro et al., 1997). It has been proposed that the $I_{\mathrm{h}}$ conductance acts to regulate the frequency of tonic inhibitory input from basket cells to principal neurons and provides the substrate for neuromodulatory transmitter control of the inhibition (Saitow and Konishi, 1999).

mHCN2 transcripts have a widespread distribution and are likely to subserve diverse roles. Because of the lack of mHCN2-specific antibodies, the subcellular localization of the respective protein is unknown. However, mHCN2 transcripts appear consistently in inhibitory GABAergic neurons, such as the short-axon cells in the olfactory bulb, hippocampal interneurons, and neurons of the thalamic reticular nucleus, globus pallidus, and substantia nigra pars reticulata. $\mathrm{mHCN} 2$ transcripts are found coupled with mHCN4 transcripts in neurons that display prominent oscillations, such as thalamocortical relay neurons. Moreover, the mHCN2 and mHCN4 isoforms are also found in the heart, suggesting their association with a pacemaking function. However, HCN4 is the predominant isoform expressed in the adult rabbit sinoatrial node, whereas mHCN2 is virtually absent from these cells but is predominant in quiescent ventricular muscle (Shi et al., 1999).

On a final note, interesting patterns of association can be observed between $I_{\mathrm{h}}$ channels and low voltage-activated T-type $\mathrm{Ca}$ channels (Talley et al., 1999), which participate in pacemaking by providing a rapid inward current that activates near threshold and contributes to the rising phase of the action potential burst (Pape, 1996). Specific associations between expression of T-type and HCN channel isoforms may help to further define the diverse physiological functions of $I_{\mathrm{h}}$ channels. For example, in inhibitory glomerular short-axon cells and reticular thalamic neurons, mHCN2 is expressed with the $\alpha 1 \mathrm{I}$ isoform of the T-type $\mathrm{Ca}$ channel. In contrast, excitatory thalamocortical relay neurons express mHCN2 and mHCN4 in association with $\alpha 1 \mathrm{G}$ T-type channels (Talley et al., 1999). In turn, mHCN1 occurs in combination with $\alpha 1 \mathrm{H}$ in layer $\mathrm{V}$ pyramidal cells and in ventromedial hypothalamic cells, as well as in spinal motorneurons (Talley et al., 1999). The particular combination of conductances that operate in the subthreshold range of potentials will define the unique firing properties of a neuron and the function of that neuron in the context of its higher order circuitry. Understanding the relationship between the different HCN channel isoforms, their association with other components of the neuronal machinery, and finally their association with specific neuronal types and functions, should open the way to the rational targeting of subtypes of these channels to correct specific cardiovascular and neurological diseases.

\section{REFERENCES}

Bland BH, Oddie SD (1998) Anatomical, electrophysiological and pharmacological studies of ascending brainstem hippocampal synchronizing pathways. Neurosci Biobehav Rev 22:259-273.

Beaumont V, Zucker RS (2000) Enhancement of synaptic transmission by cyclic AMP modulation of presynaptic Ih channels. Nat Neurosci 3:133-141.

Clapham DE (1998) Not so funny anymore: pacing channels are cloned. Neuron 21:5-7.

DiFrancesco D (1993) Pacemaker mechanisms in cardiac tissue. Annu Rev Physiol 55:455-472.

DiFrancesco D, Mangoni M (1994) Modulation of single hyperpolarization-activated channels (i(f)) by cAMP in the rabbit sinoatrial node. J Physiol (Lond) 474:473-482.

DiFrancesco D, Tortora P (1991) Direct activation of cardiac pacemaker channels by intracellular cyclic AMP. Nature 351:145-147.

Dodt HU, Zieglgansberger W (1990) Visualizing unstained neurons in living brain slices by infrared DIC-videomicroscopy. Brain Res 537:333-336.

Fletcher GH, Chiappinelli VA (1992) An inward rectifier is present in presynaptic nerve terminals in the chick ciliary ganglion. Brain Res 575:103-112.

Franklin KBJ, Paxinos G (1997) The mouse brain in stereotaxic coordinates. San Diego: Academic.

Ingram SL, Williams JT (1996) Modulation of the hyperpolarizationactivated current $\left(I_{h}\right)$ by cyclic nucleotides in guinea-pig primary afferent neurons. J Physiol (Lond) 492:97-106.

Ishii TM, Takano M, Xie LH, Noma A, Ohmori H (1999) Molecular characterization of the hyperpolarization-activated cation channel in rabbit heart sinoatrial node. J Biol Chem 274:12835-12839.

Kawaguchi Y (1992) Large aspiny cells in the matrix of the rat neostria- 
tum in vitro: physiological identification, relation to the compartments and excitatory postsynaptic currents. J Neurophysiol 67:1669-1682.

Kawaguchi Y (1993) Physiological, morphological, and histochemical characterization of three classes of interneurons in rat neostriatum. J Neurosci 13:4908-4923.

Jiang ZG, North RA (1991) Membrane properties and synaptic responses of rat striatal neurones in vitro. J Physiol (Lond) 443:533-553.

Ludwig A, Zong X, Jeglitsch M, Hofmann F, Biel M (1998) A family of hyperpolarization-activated mammalian cation channels. Nature 393:587-591.

Ludwig A, Zong X, Stieber J, Hullin R, Hofmann F, Biel M (1999) Two pacemaker channels from human heart with profoundly different activation kinetics. EMBO J 18:2323-2329.

Lüthi A, McCormick DA (1998) H-current: properties of a neuronal and network pacemaker. Neuron 21:9-12.

Lüthi A, McCormick DA (1999) Modulation of a pacemaker current through $\mathrm{Ca}(2+)$-induced stimulation of cAMP production. Nat Neurosci 2:634-641.

Maccaferri G, McBain CJ (1996) The hyperpolarization-activated current $\left(\mathrm{I}_{\mathrm{h}}\right)$ and its contribution to pacemaker activity in rat CA1 hippocampal stratum oriens-alveus interneurones. J Physiol (Lond) 497:119-130.

Magee JC (1999) Dendritic lh normalizes temporal summation in hippocampal CA1 neurons. Nat Neurosci 2:508-514.

Magee JC (1998) Dendritic hyperpolarization-activated currents modify the integrative properties of hippocampal CA1 pyramidal neurons. J Neurosci 18:7613-7624.

McCormick DA, Bal T (1997) Sleep and arousal: thalamocortical mechanisms Annu Rev Neurosci 20:185-215.

McCormick DA, Pape HC (1990) Properties of a hyperpolarizationactivated cation current and its role in rhythmic oscillation in thalamic relay neurones. J Physiol (Lond) 431:291-318.

McCormick DA, Prince DA (1987) Acetylcholine causes rapid nicotinic excitation in the medial habenular nucleus of guinea pig, in vitro. J Neurosci 7:742-752.

Moosmang S, Biel M, Hofmann F, Ludwig A (1999) Differential distribution of four hyperpolarization-activated cation channels in mouse brain. J Biol Chem 380:975-980.

Moroni A, Barbuti A, Altomare C, Viscomi C, Morgan J, Baruscotti M, DiFrancesco D (2000) Kinetic and ionic properties of the human HCN2 pacemaker channel. Pflügers Arch 439:618-626.

Neher E (1992) Correction for liquid junction potentials in patch clamp experiments. Methods Enzymol 207:123-131.

Nicoll A, Larkman A, Blakemore C (1993) Modulation of EPSP shape and efficacy by intrinsic membrane conductances in rat neocortical pyramidal neurons in vitro. J Physiol (Lond) 468:693-710.

Pape HC (1996) Queer current and pacemaker: the hyperpolarizationactivated cation current in neurons. Annu Rev Physiol 58:299-327.

Robinson RB, Yu H, Chang F, Cohen IS (1997) Developmental change in the voltage-dependence of the pacemaker current, if, in rat ventricle cells. Pflügers Arch 433:533-535.

Saito Y, Isa T (1999) Electrophysiological and morphological properties of neurons in the rat superior colliculus. I Neurons in the intermediate layer. J Neurophysiol 82:754-767.

Saitow F, Konishi S (1999) $\beta$-adrenergic receptor mediated excitability increase via activation of a hyperpolarization activated current $\left(\mathrm{I}_{\mathrm{h}}\right)$ in rat cerebellar basket cells. Soc Neurosci Abstr 25:1255.

Santoro B, Tibbs GR (1999) The HCN gene family: molecular basis of the hyperpolarization-activated pacemaker channels. Ann NY Acad Sci 868:741-764.

Santoro B, Grant SG, Bartsch D, Kandel ER (1997) Interactive cloning with the SH3 domain of N-src identifies a new brain specific ion channel protein, with homology to eag and cyclic nucleotide-gated channels. Proc Natl Acad Sci USA 94:14815-14820.

Santoro B, Liu DT, Yao H, Bartsch D, Kandel ER, Siegelbaum SA, Tibbs GR (1998) Identification of a gene encoding a hyperpolarizationactivated pacemaker channel of brain. Cell 93:717-729.

Schaeren-Wiemers N, Gerfin-Moser A (1993) A single protocol to detect transcripts of various types and expression levels in neural tissue and cultured cells: in situ hybridization using digoxigenin-labelled cRNA probes. Histochemistry 100:431-440.

Seifert R, Scholten A, Gauss R, Mincheva A, Lichter P, Kaupp UB (1999) Molecular characterization of a slowly gating human hyperpolarizationactivated channel predominantly expressed in thalamus, heart, and testis. Proc Natl Acad Sci USA 96:9391-9396.

Shi W, Wymore R, Yu H, Wu J, Wymore RT, Pan Z, Robinson RB, Dixon JE, McKinnon D, Cohen IS (1999) Distribution and prevalence of hyperpolarization-activated cation channel (HCN) mRNA expression in cardiac tissues. Circ Res 85:E1-E6.

Stanford IM, Cooper AJ (1999) Presynaptic mu and delta opioid receptor modulation of GABAA IPSC s in the rat globus pallidus in vitro. J Neurosci 19:4796-4803.

Stuart G, Spruston N (1998) Determinants of voltage attenuation in neocortical pyramidal neuron dendrites. J Neurosci 18:3501-3510.

Talley EM, Cribbs LL, Lee JH, Daud A, Perez-Reyes E, Bayliss DA (1999) Differential distribution of three members of a gene family encoding low voltage-activated (T-type) calcium channels. J Neurosci 19:1895-1911.

Vaccari T, Moroni A, Rocchi M, Gorza L, Bianchi ME, Beltrame M, DiFrancesco D (1999) The human gene coding for HCN2, a pacemaker channel of the heart. Biochim Biophys Acta 1446:419-425.

Vinogradova OS, Kitchigina VF, Zenchenko CI (1998) Pacemaker neurons of the forebrain medical septal area and theta rhythm of the hippocampus. Membr Cell Biol 11:715-725.

Williams S, Samulack DD, Beaulieu C, LaCaille JC (1994) Membrane properties and synaptic responses of interneurons located near the stratum lacunosum-moleculare/radiatum border of area CA1 in whole-cell recordings from rat hippocampal slices. J Neurophysiol 71:2217-2235.

Williams SR, Turner JP, Hughes SW, Crunelli V (1997) On the nature of anomalous rectification in thalamocortical neurones of the cat ventrobasal thalamus in vitro. J Physiol (Lond) 505:727-747.

Yu H, Chang F, Cohen IS (1993) Pacemaker current exists in ventricular myocytes. Circ Res 72:232-236. 